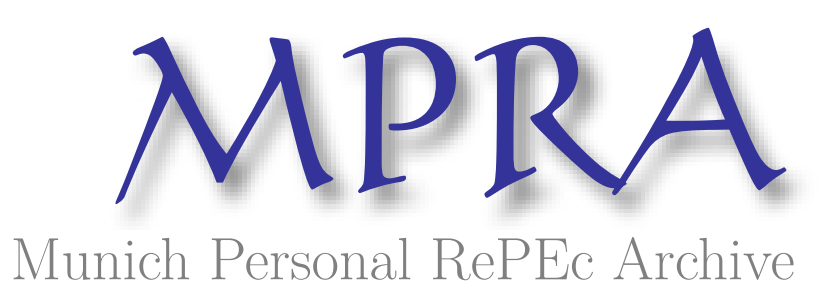

\title{
Process of privatization in Bulgaria
}

Pamouktchiev, Hristo and Parvulov, Svilen and Petranov, Stefan

1997

Online at https://mpra.ub.uni-muenchen.de/107452/

MPRA Paper No. 107452, posted 01 May 2021 06:46 UTC 


\section{(D)}
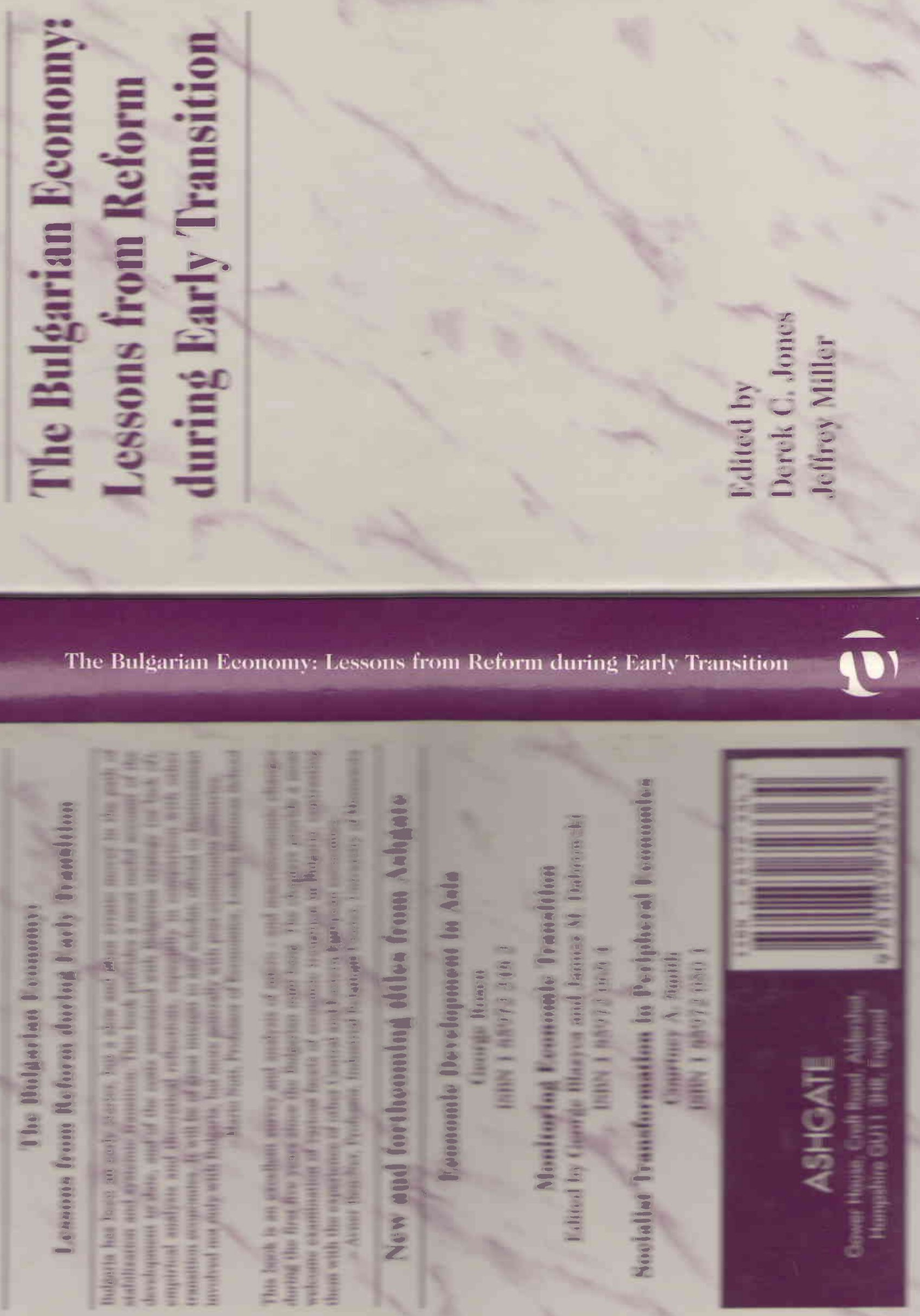


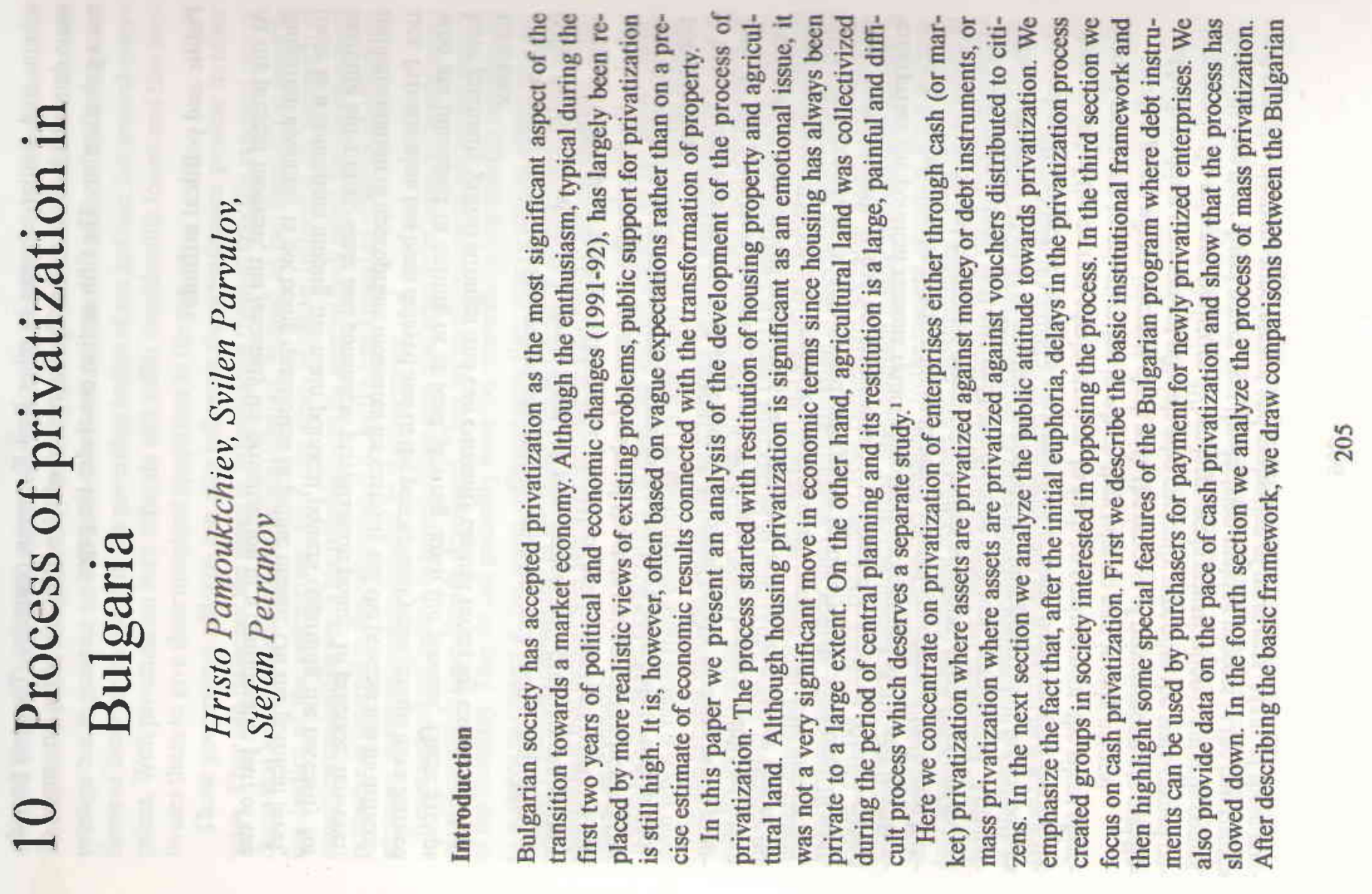




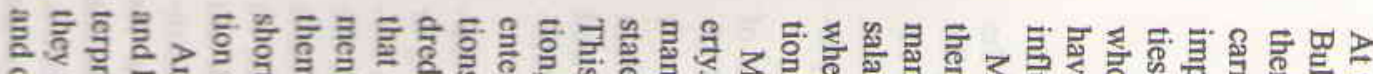

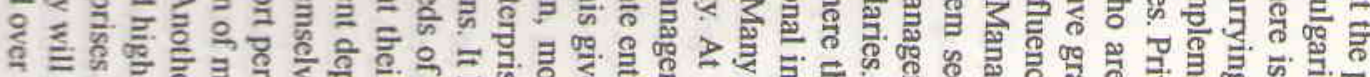

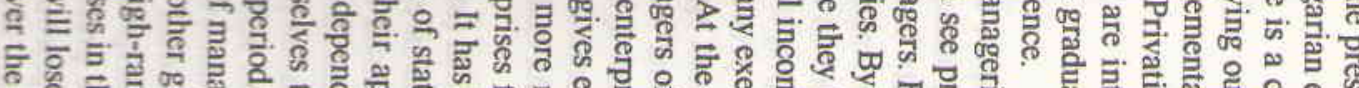

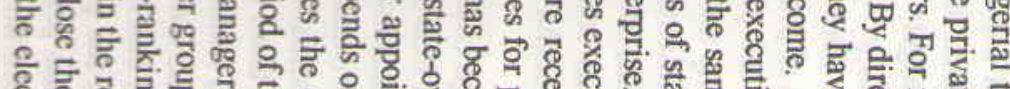

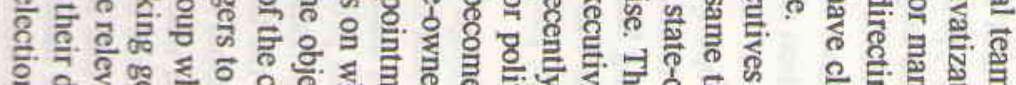

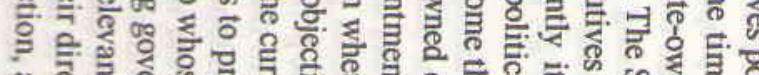

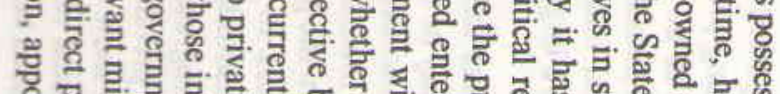

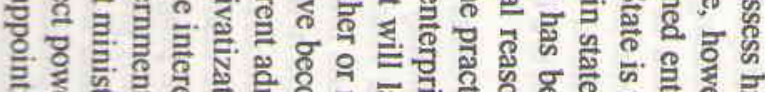

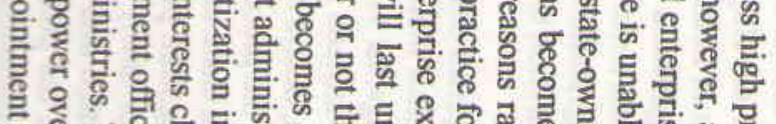

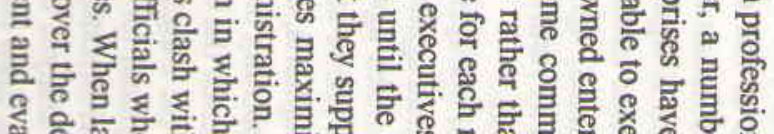

₹

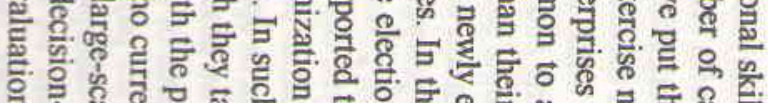

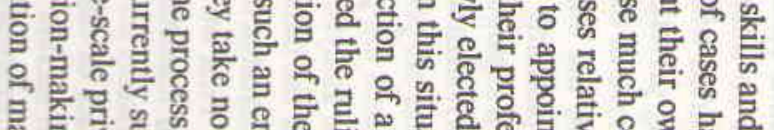

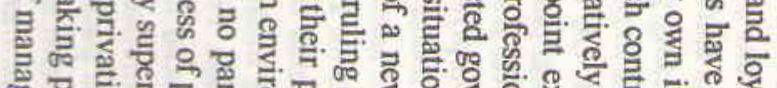

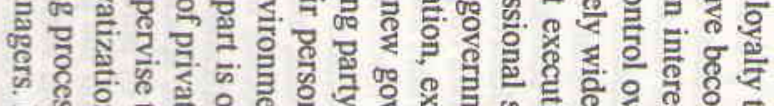
3내을

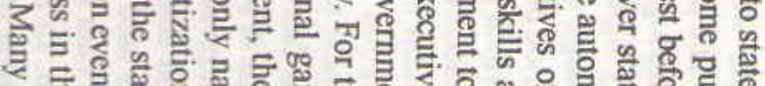

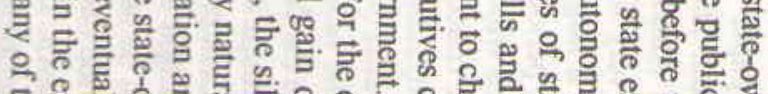

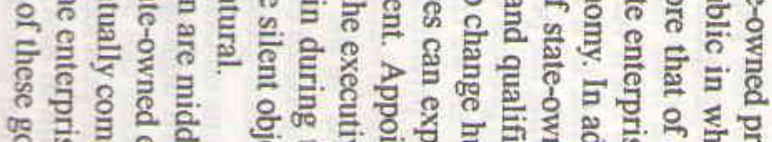

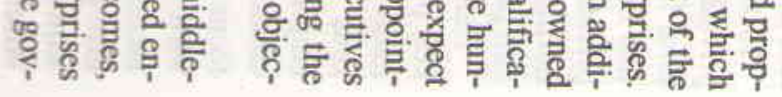

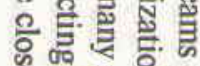

(1)

8 它

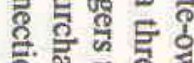

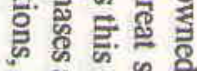

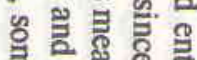

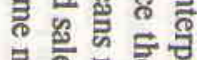

콩

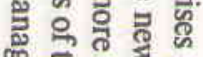

연

告

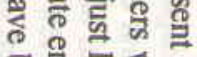

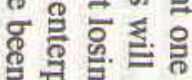

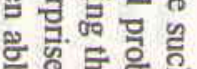

등

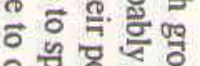

융 휴율

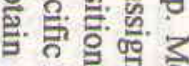

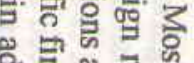

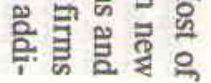

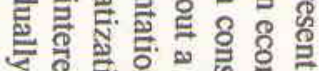

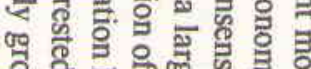

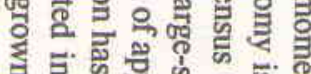

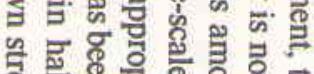

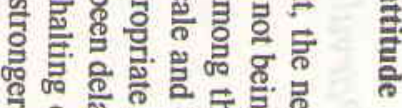

웡

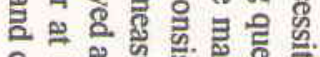

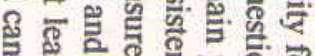

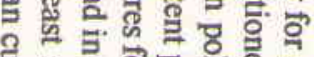

声 등혐믈.

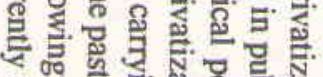

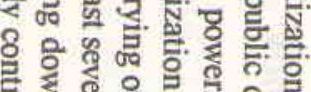

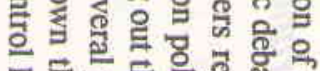

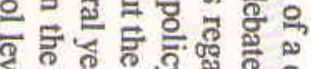

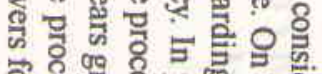

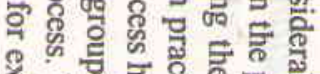

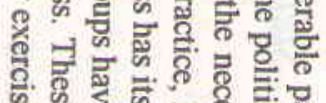

空: है

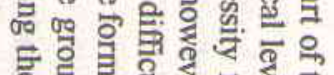

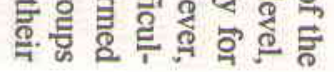

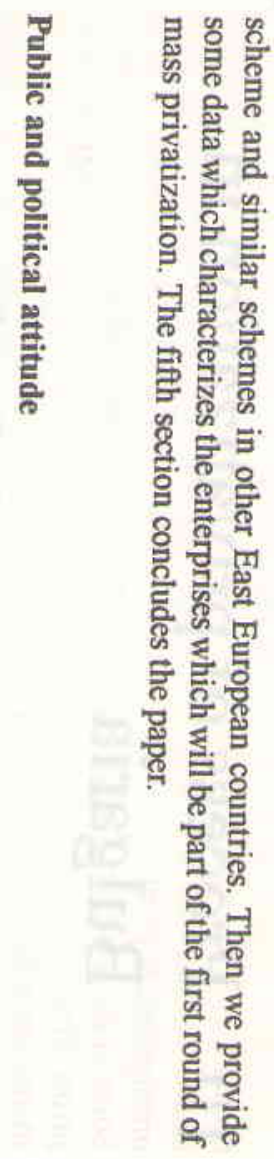

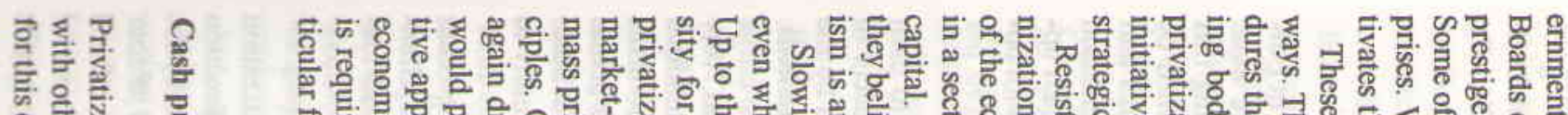

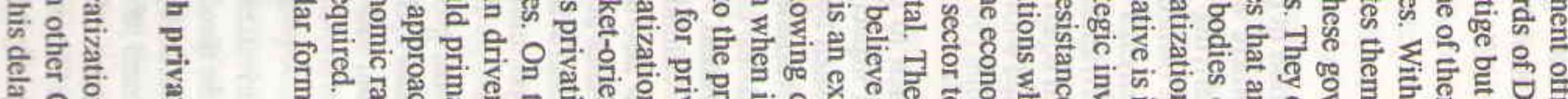

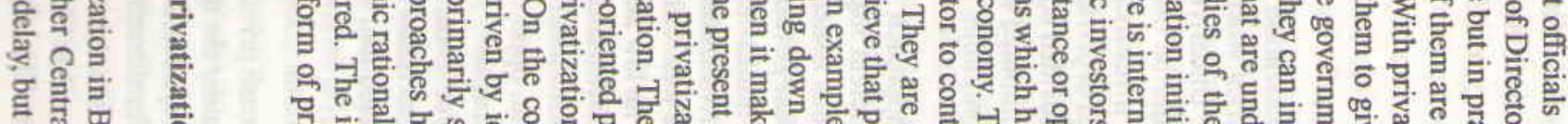

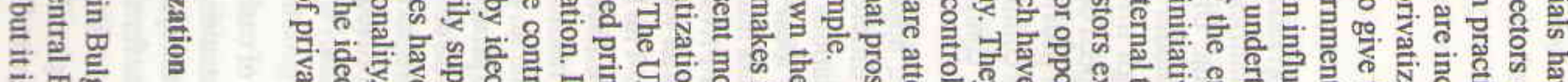

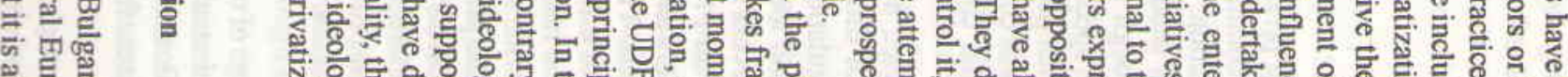

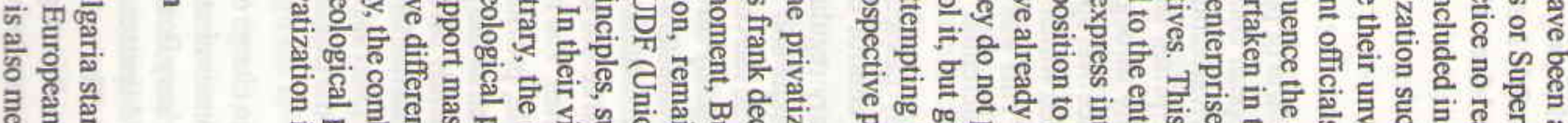
ज् 8 . 률 要 इं : है 웅

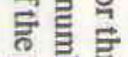

귬

政

品

屈

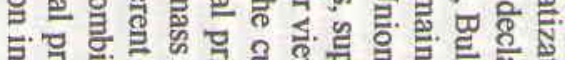
蛋

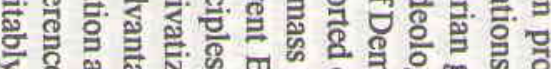

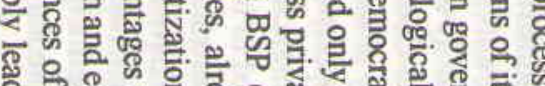

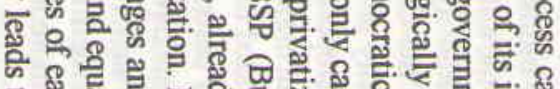
б

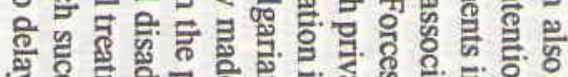

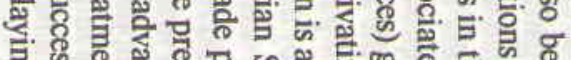

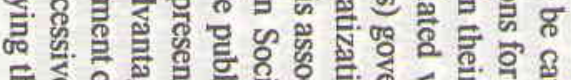

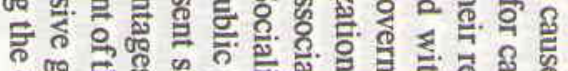

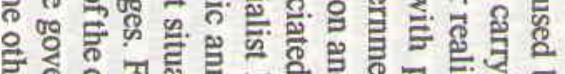
대을

舅

롱 它色 ช

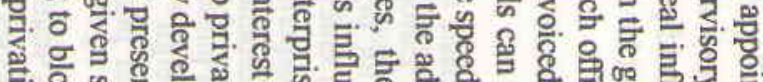

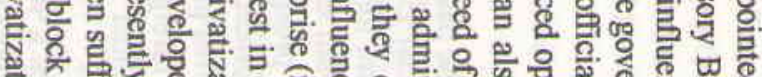
吥

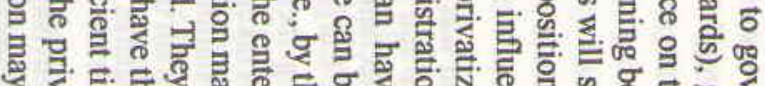

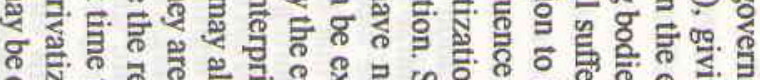

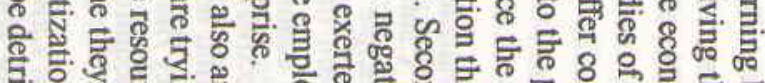

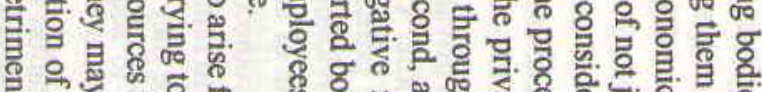

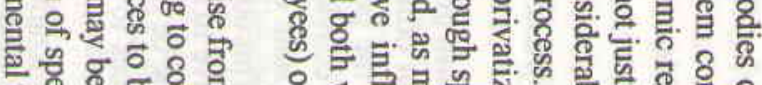
훙.

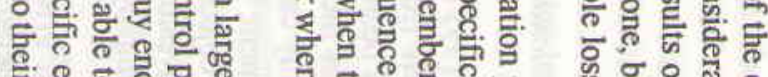

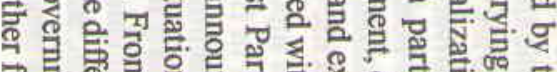

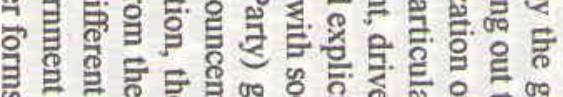

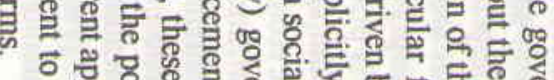

…유

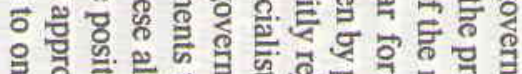

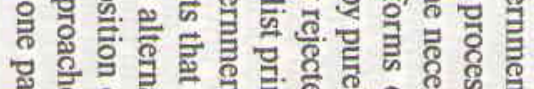

की

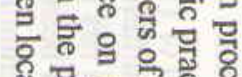

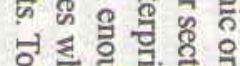

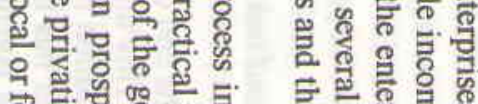

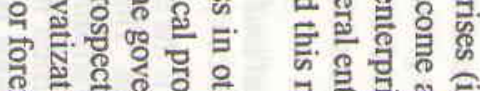

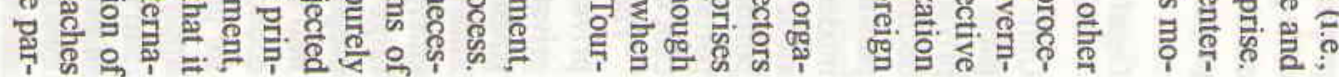




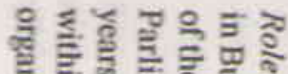
당 드류.

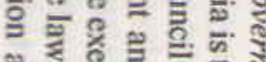

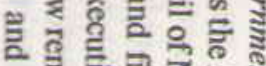
응 츌류?

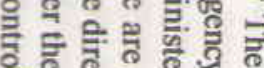
응

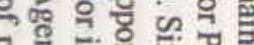

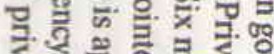

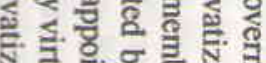

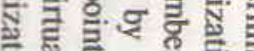

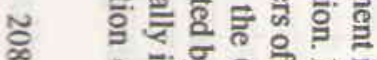
콜

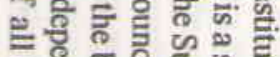

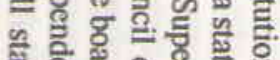

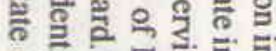

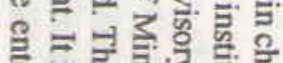

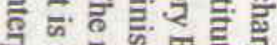

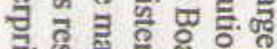
(5)

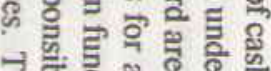
글

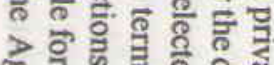

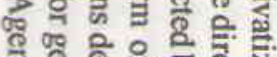

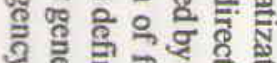

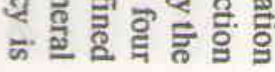

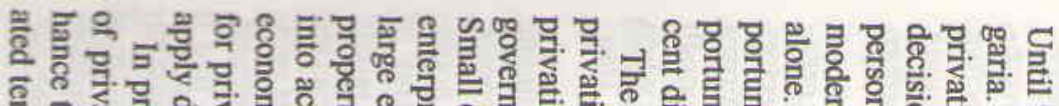

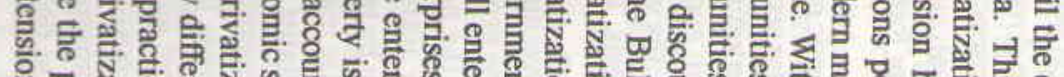

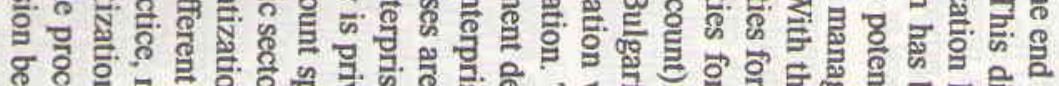

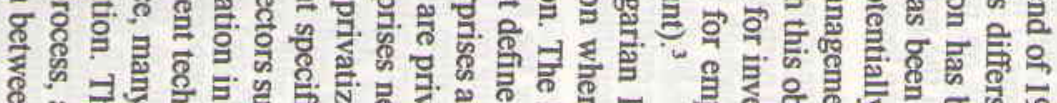
舟

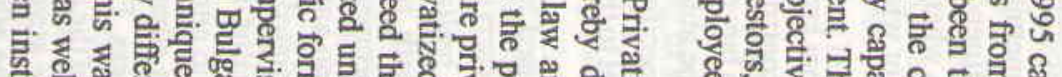
․ㅡㄹ

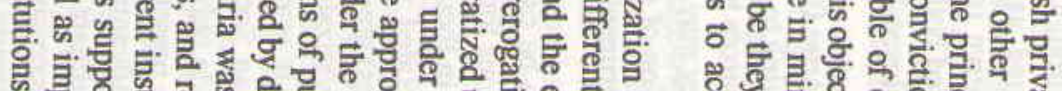

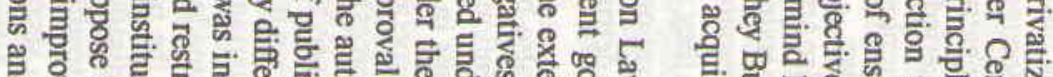

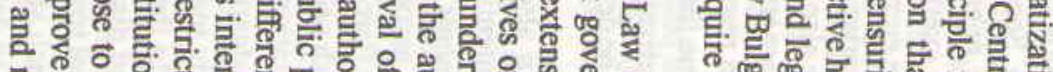

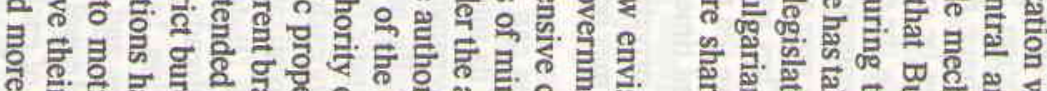

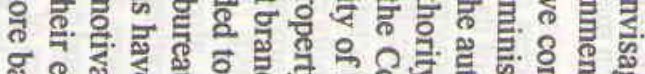

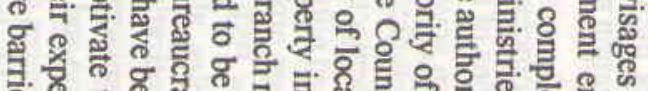
응 \%

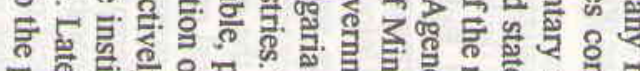
임현

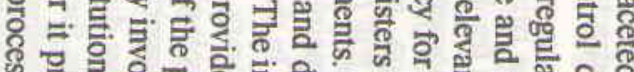

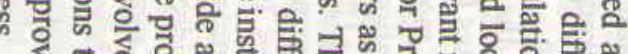
영응

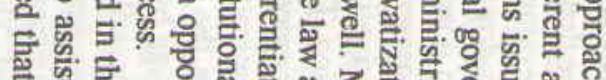

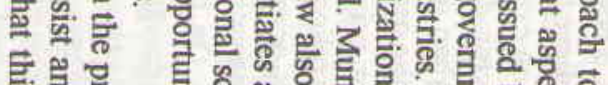

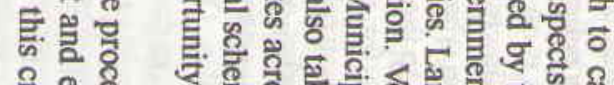

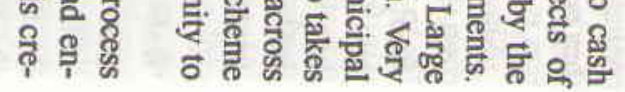

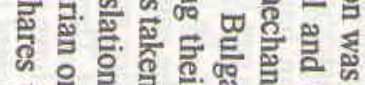

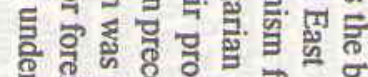

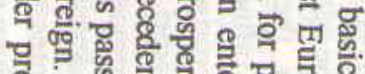

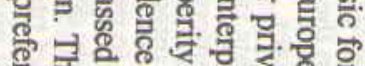
를 응 9

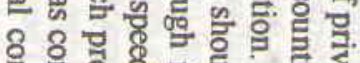

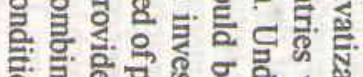

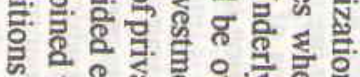

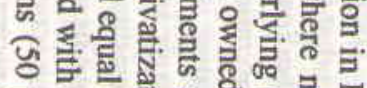

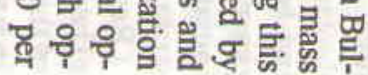
兽

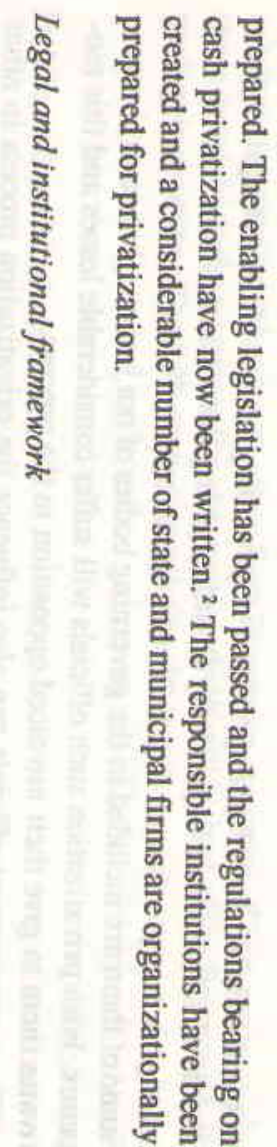

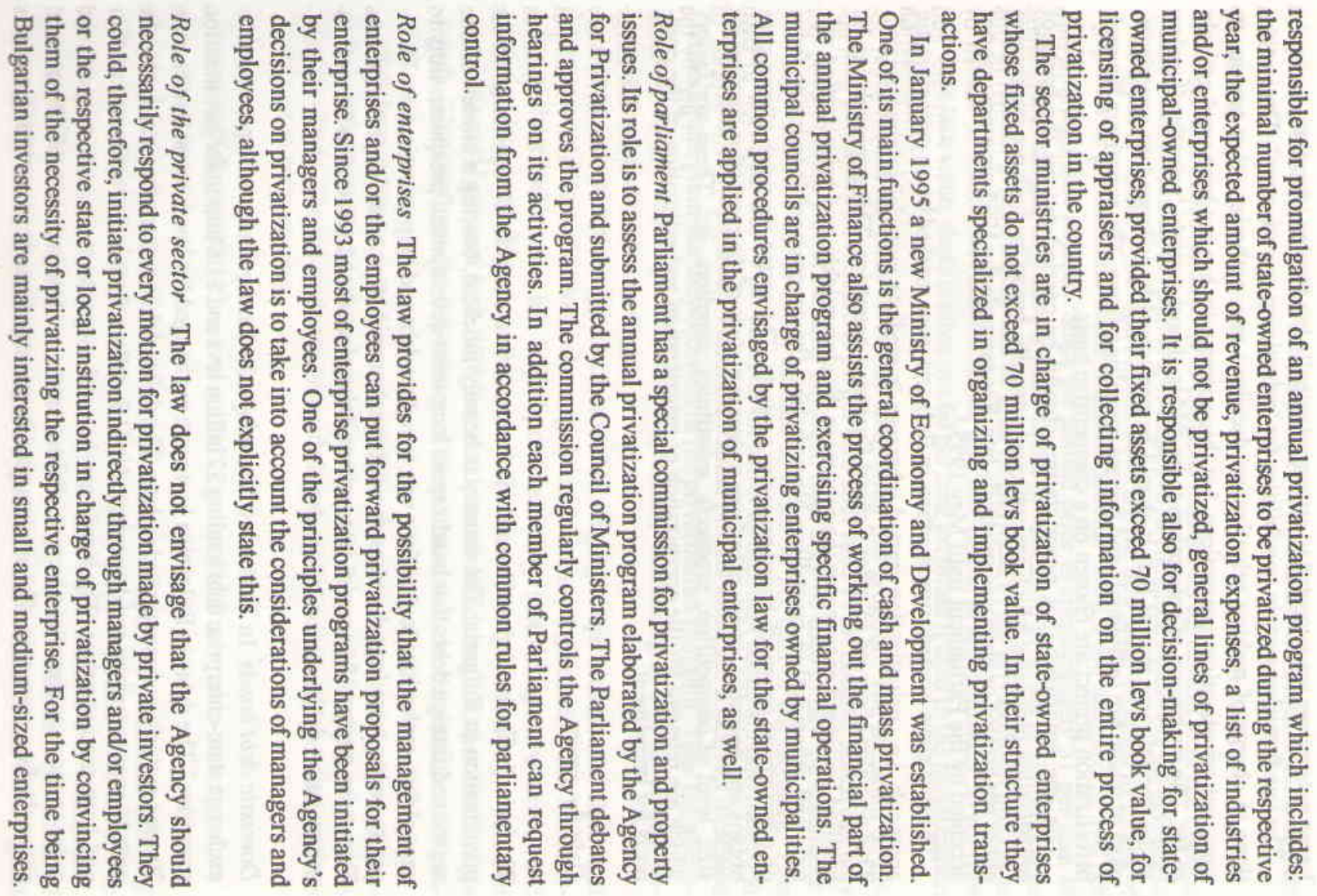




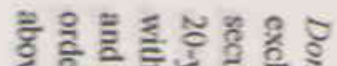
क्षे ॠᄒ

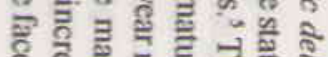
8 列 를 ซ

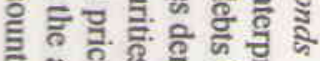

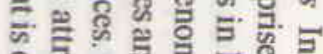

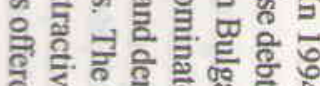

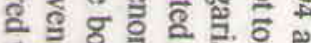

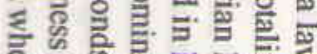

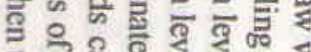

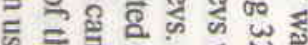

등 한.

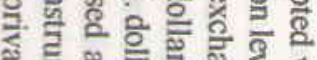

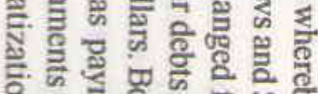

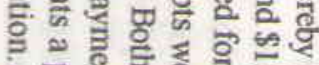
$\geq$ 品

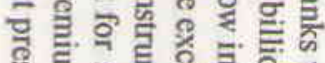

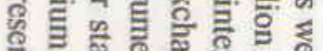
政

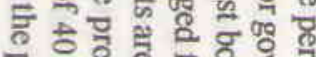

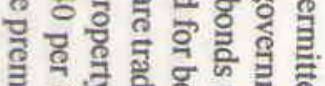

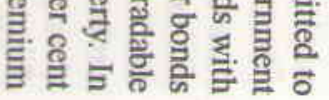

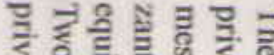

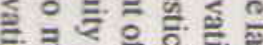
政:

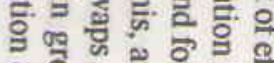

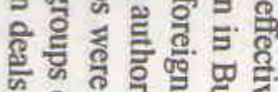
올 응 응

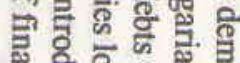

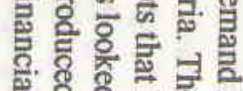
. -

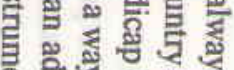
党 专

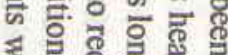
就 요을 을. 풍두응 을 율 융 응

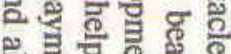
일를.

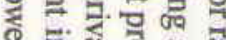

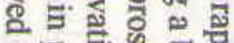
5 몽

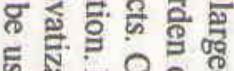

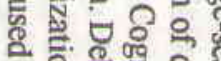

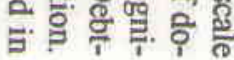

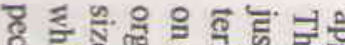

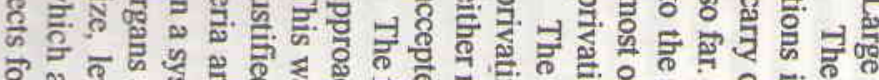

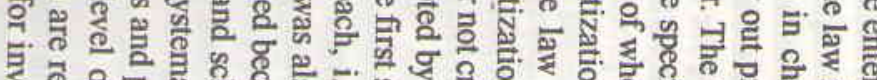

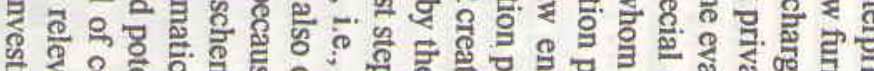
1

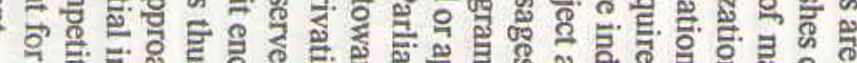

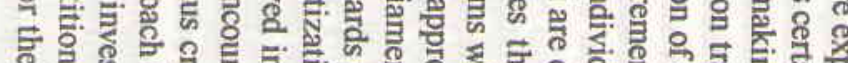

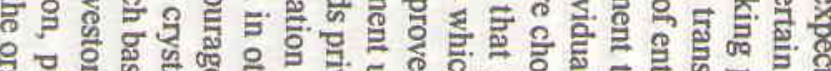

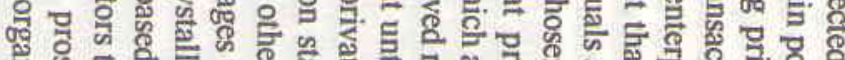
的

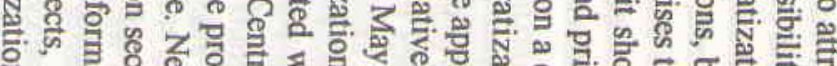

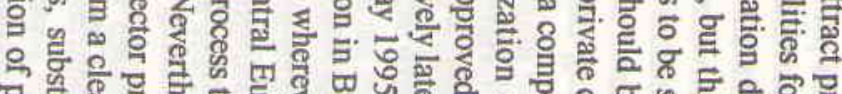

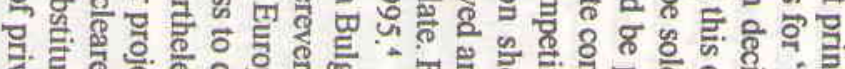

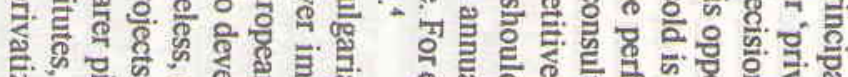

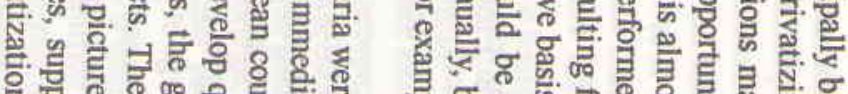

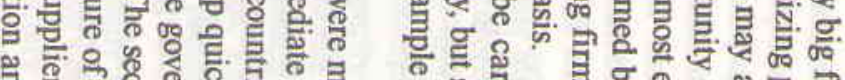

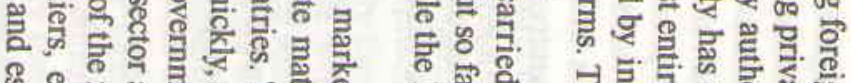
8.

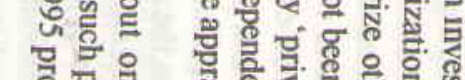
等

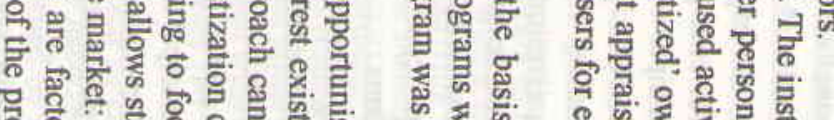

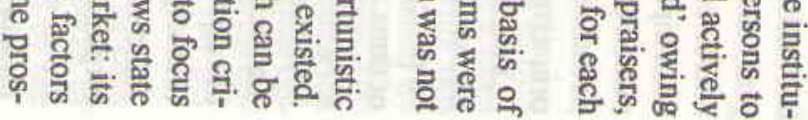

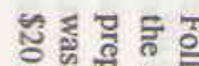
킁.

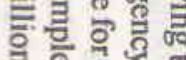

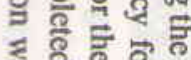
政 s. 다을 올 응

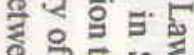
sis

F。

$\cong$ 골

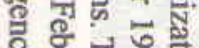

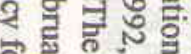

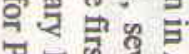

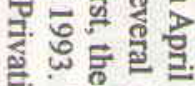

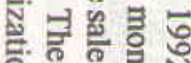

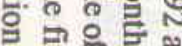
일

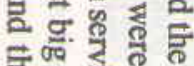

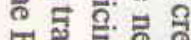
喝

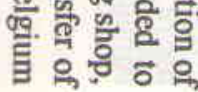

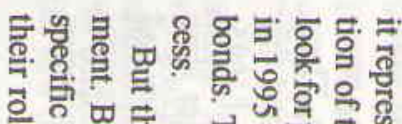

䙳

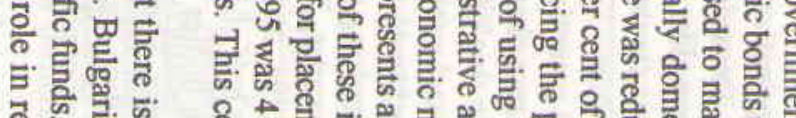

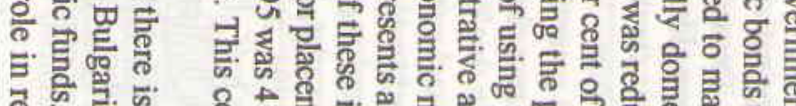

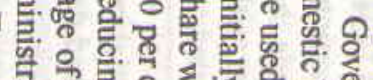

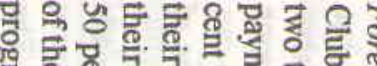
负

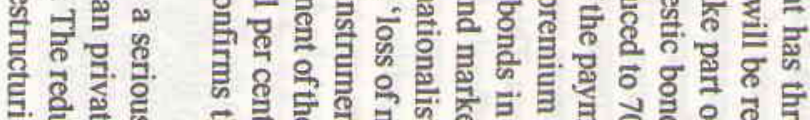

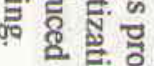

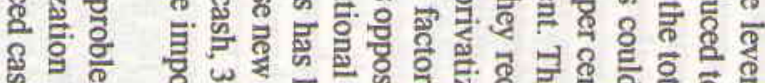
공

응 은

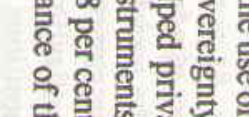

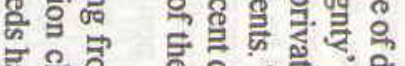

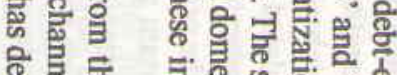

敦言 赔产 政总 政富

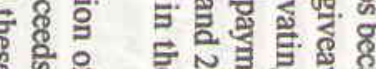

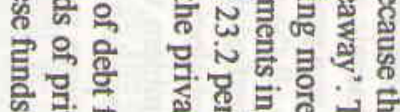

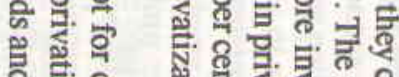

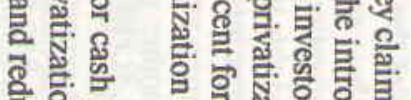

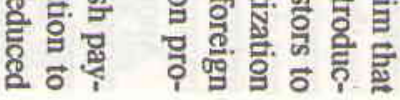
4

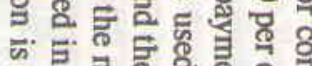

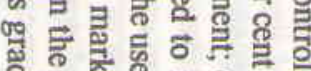

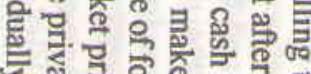

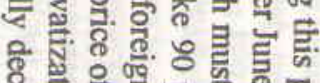

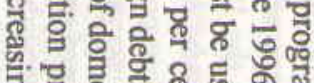

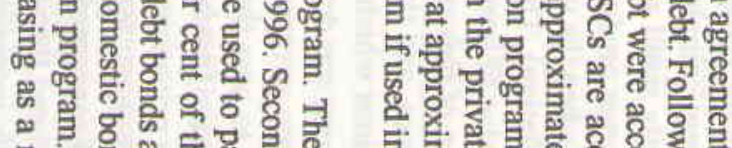

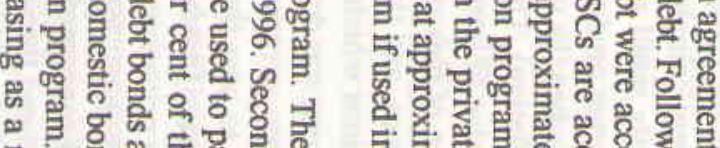

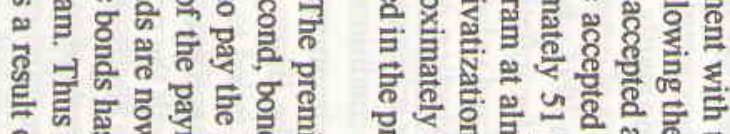
סิ

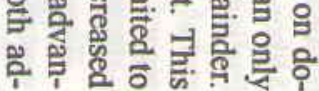
宽

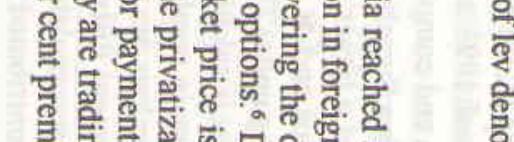

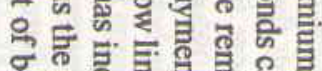
ฐ.

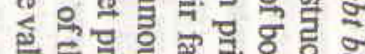

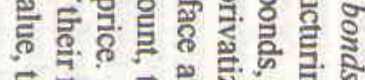

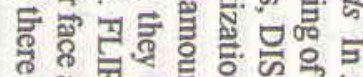
w.

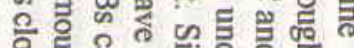

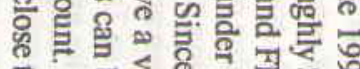

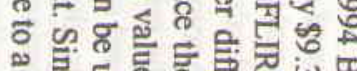
a

骂

品

롤

$\stackrel{\Rightarrow}{0}$

ก

ह

हैं

층

긍

혁 후을 罚 乎

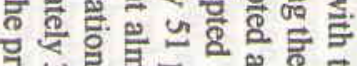
.

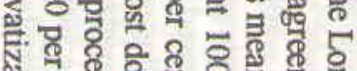

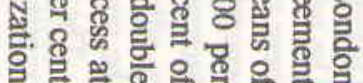




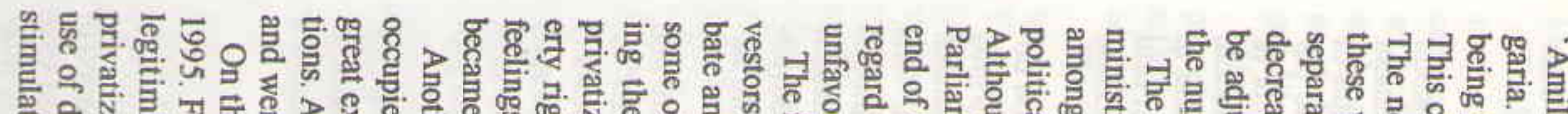

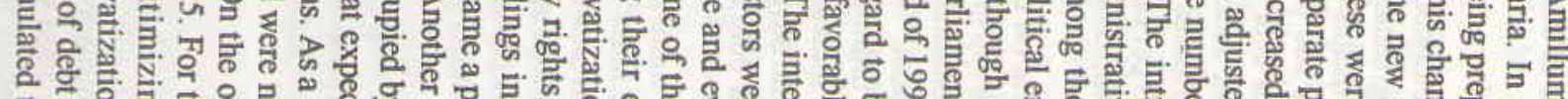

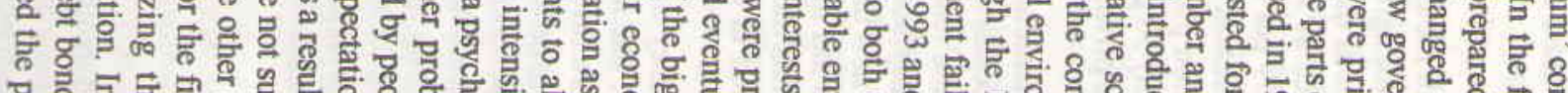
苋

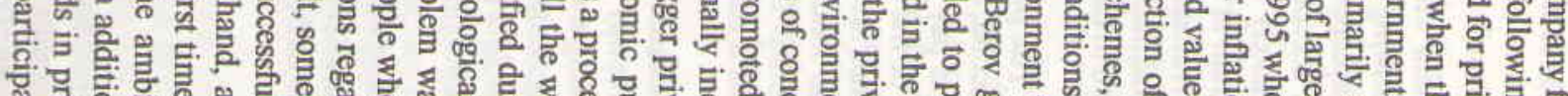

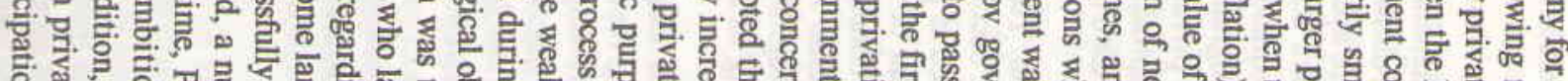

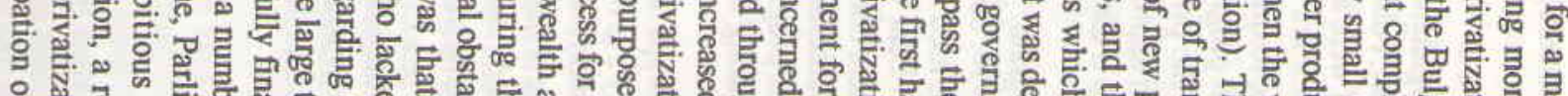

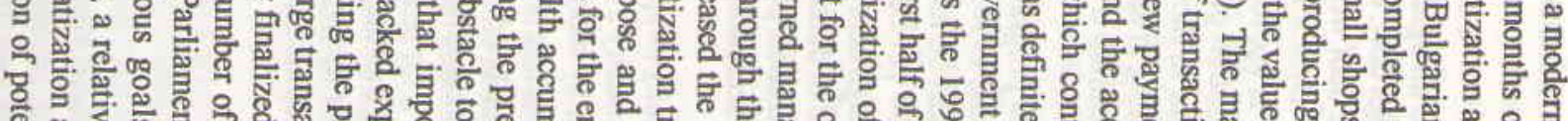
引

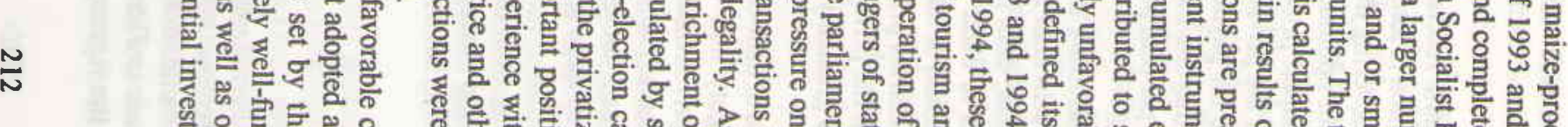

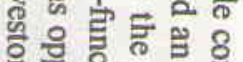

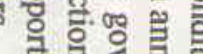
药

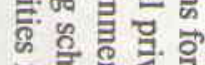

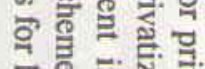

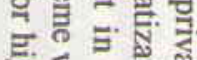

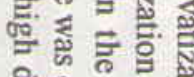

듕 율 $\Rightarrow$ 空

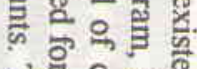

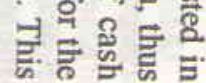

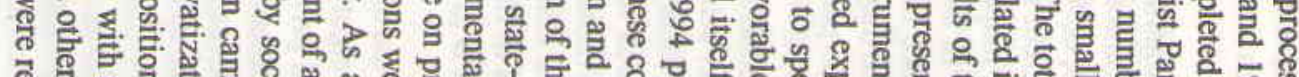

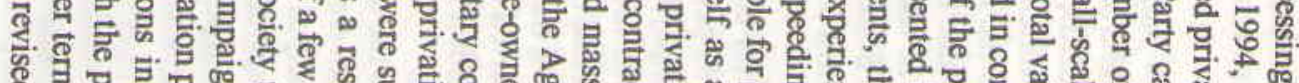

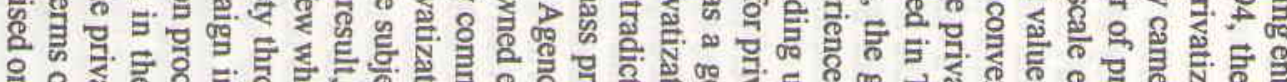

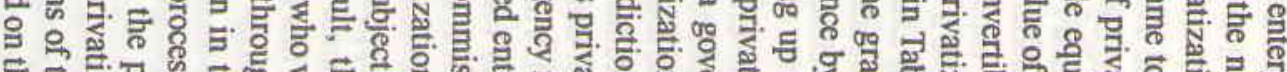

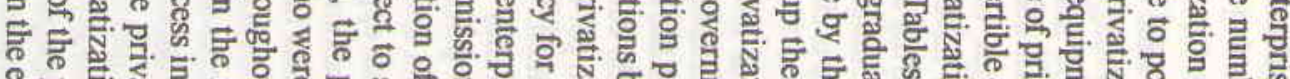

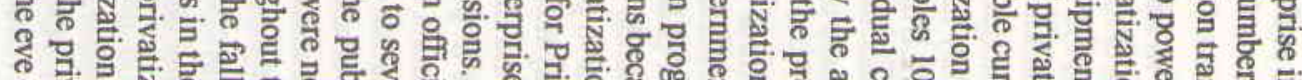

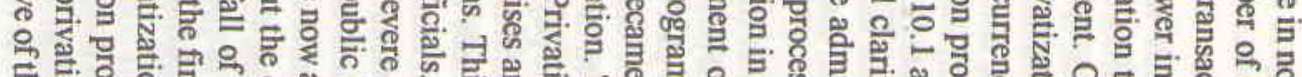

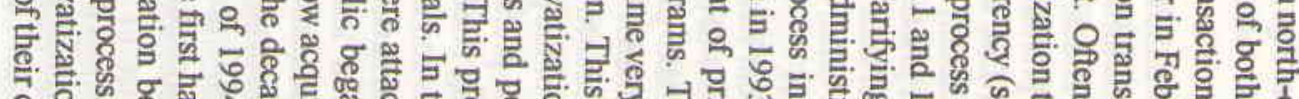

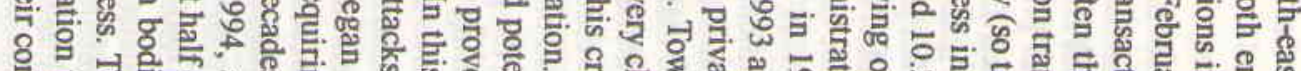
혁형유. 商.

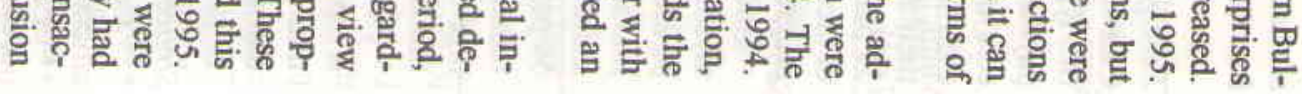

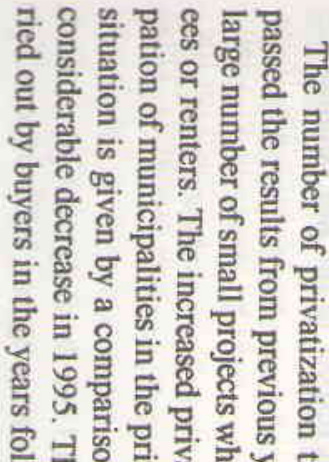

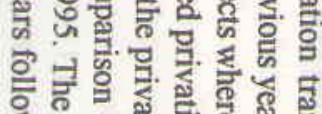

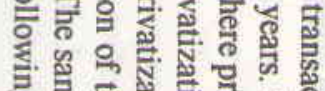

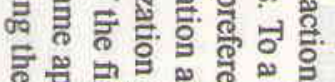

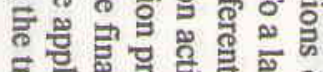

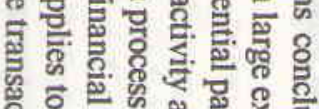

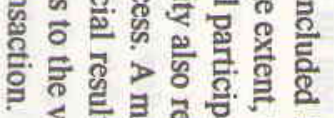

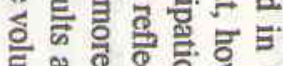
官

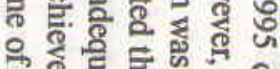

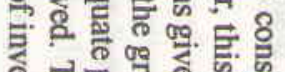

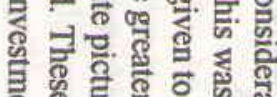

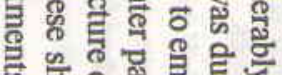

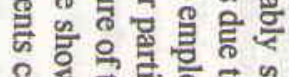

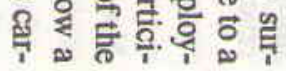

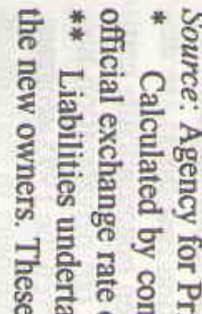
흥을 드을 흘 둘

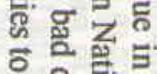
능 Co 들 는 을 年 兽 量 要 50 क्ष
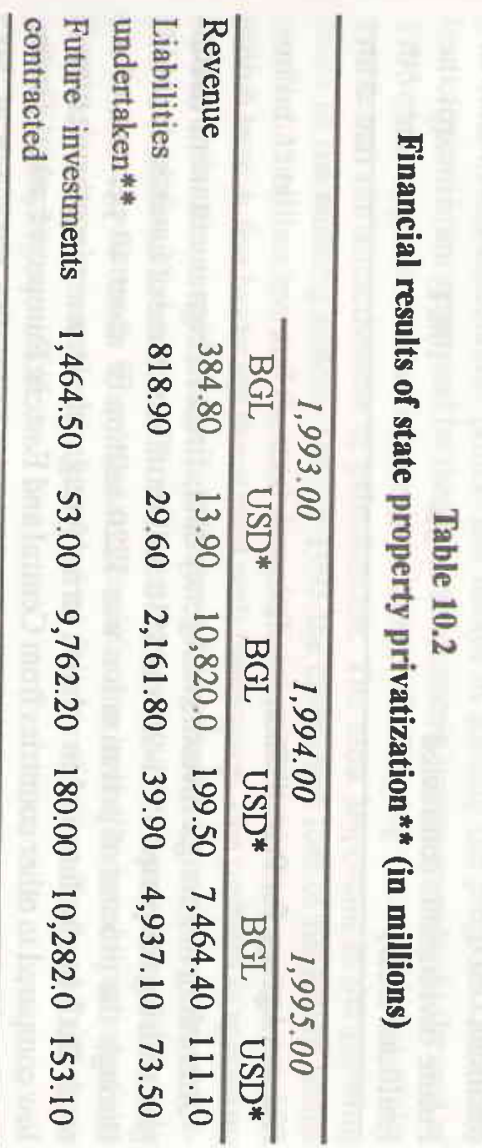

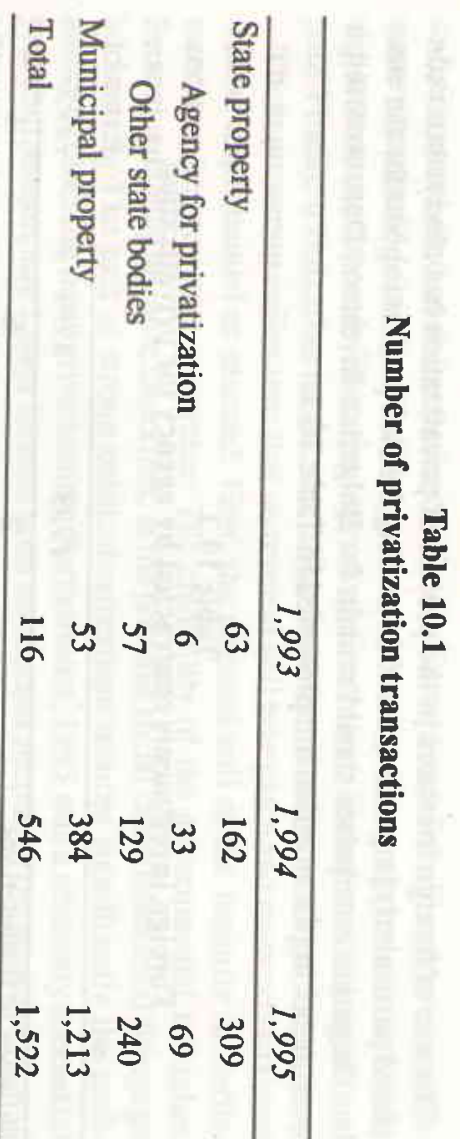




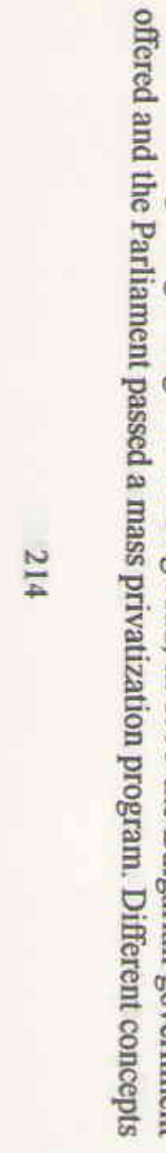

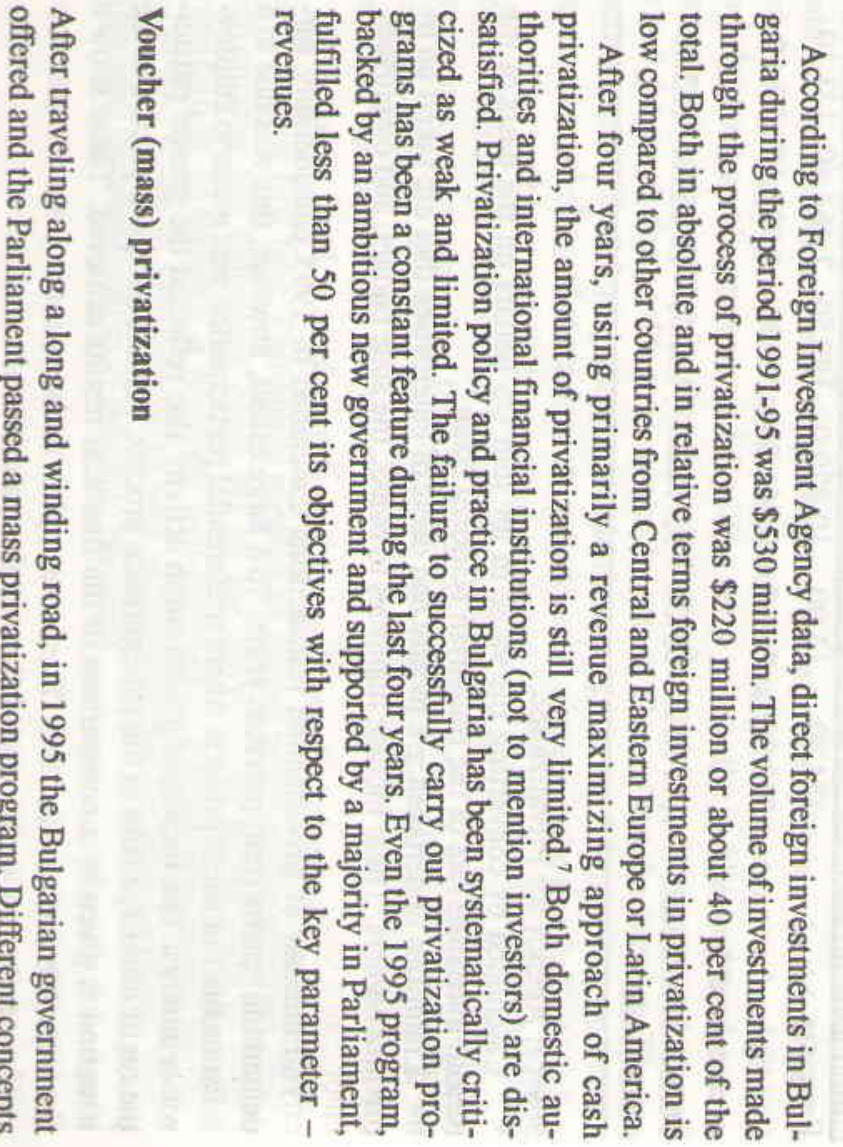

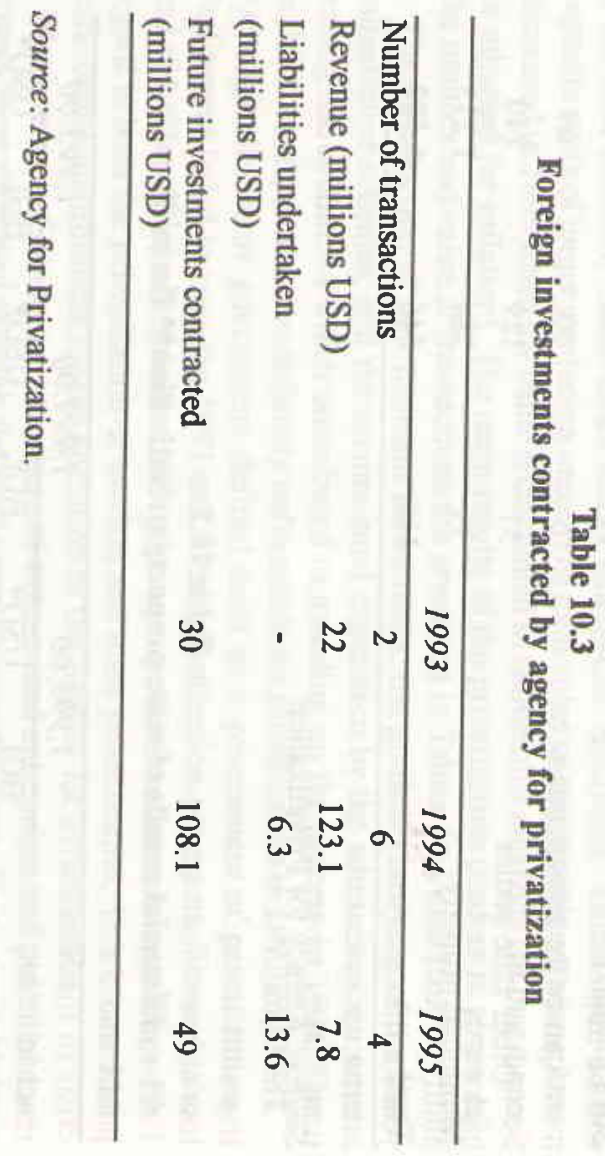

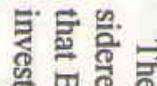
范茞

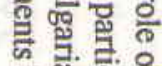

코융

․ㅡㄹ

고ㅇㅛㅛ

등 क

홍

흘흐

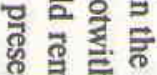

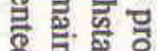

ㅎ. 울

붕요

흥 है चु

그. 2 ?

焉

ㅋ. 응

ฏ

을 है

붕

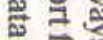

욱 क

응

옹. 올

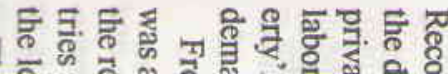
ह ठํㅠ.

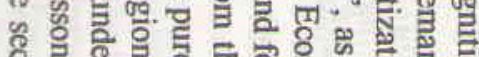
은

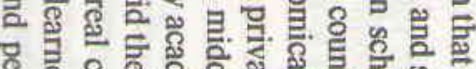

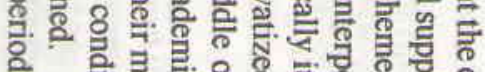

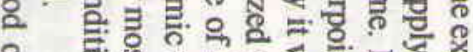
竞

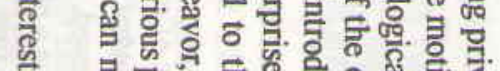

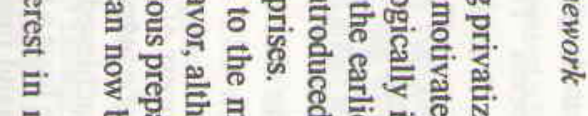

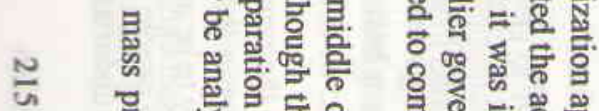

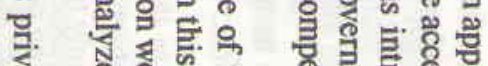

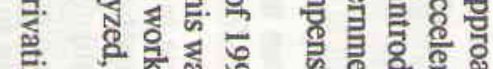

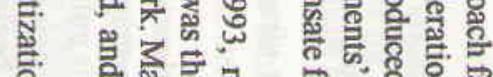

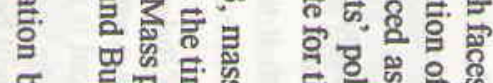

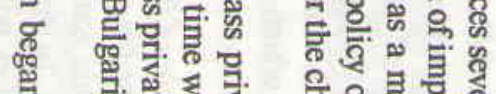

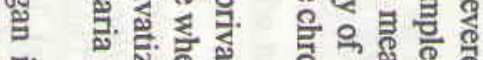

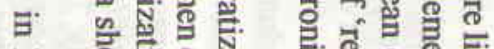

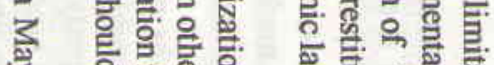

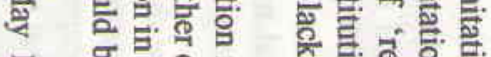

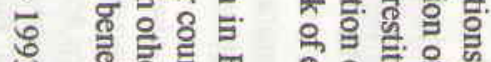
-

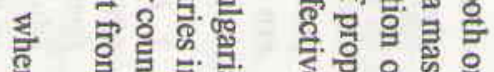

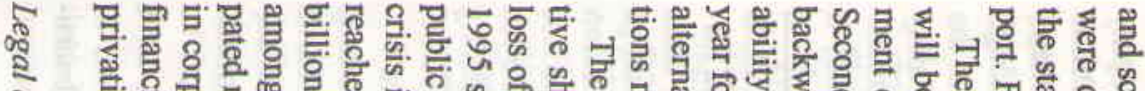

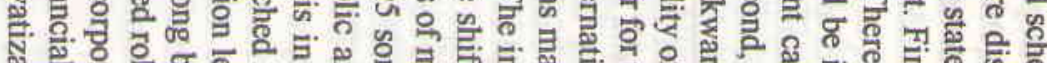

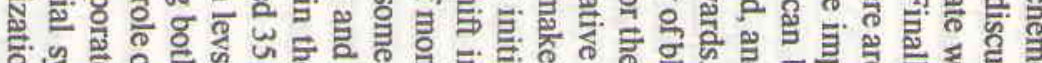
氜 응 品 象

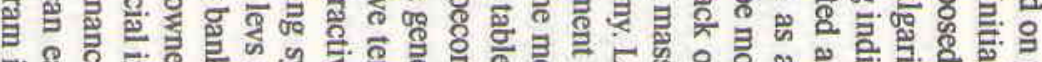

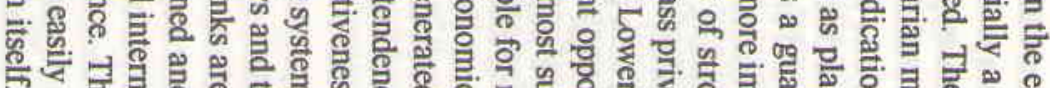
б ह 它

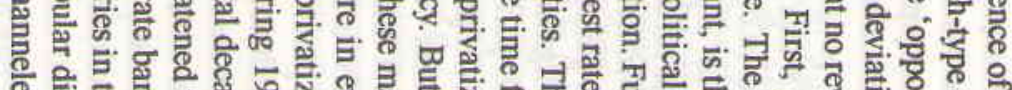

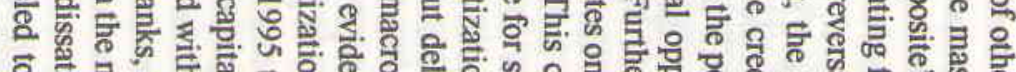

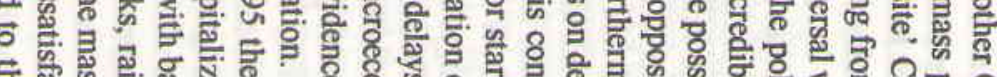

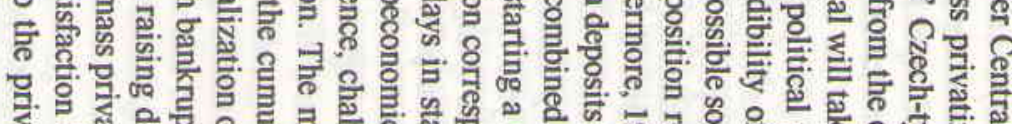
․ㅜㄴ.

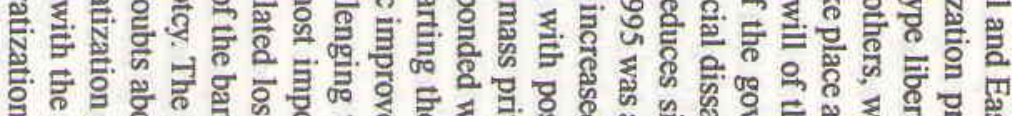

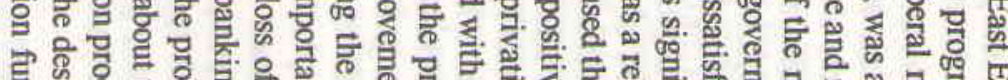

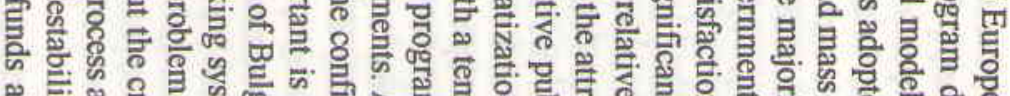

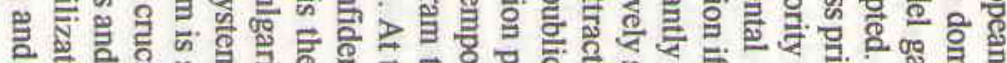
है

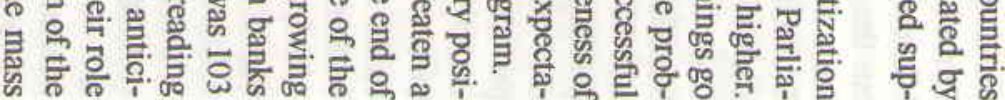




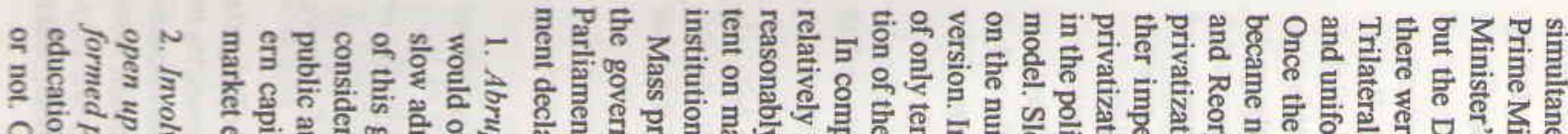

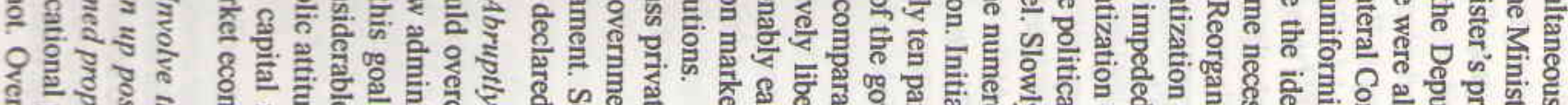
司

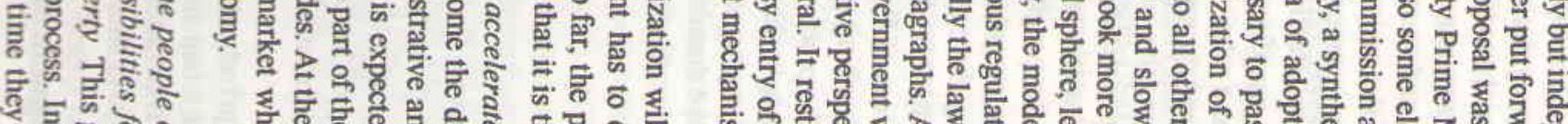

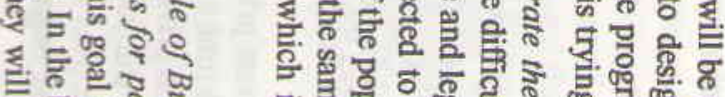

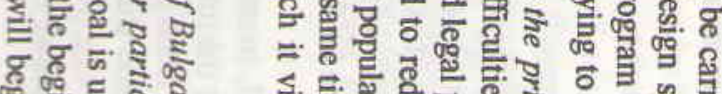

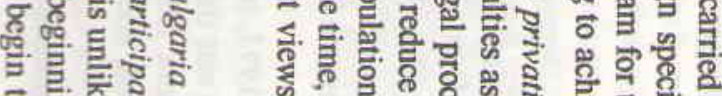
다유.

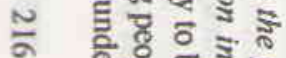
के

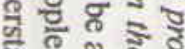
를 है

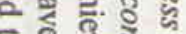

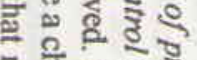

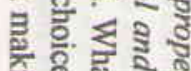

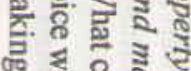

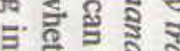

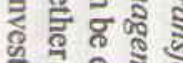

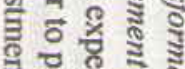
कृष 긍.

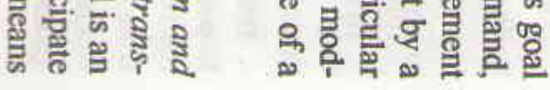
है

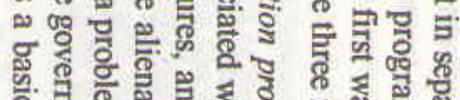

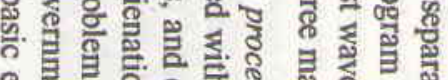
응

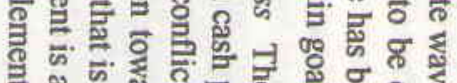

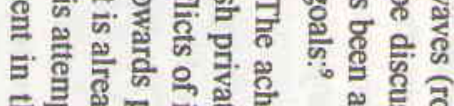
है믈.

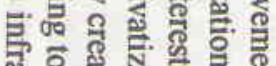

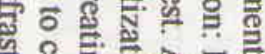

䓀产

के

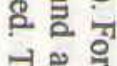
हैं ํㅠㅇ 웅

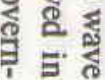

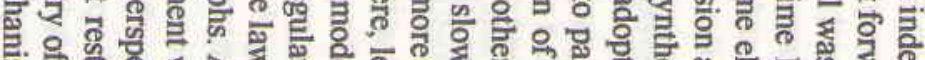
勿等.

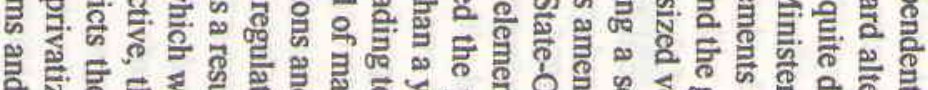

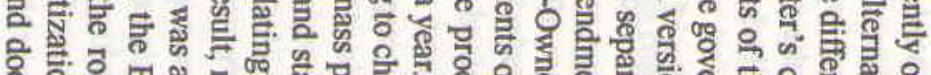

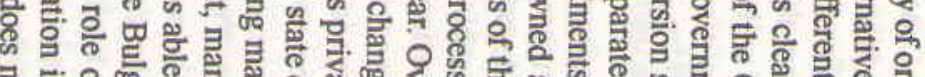

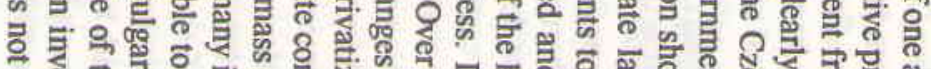

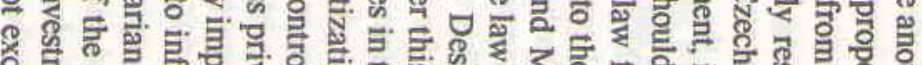

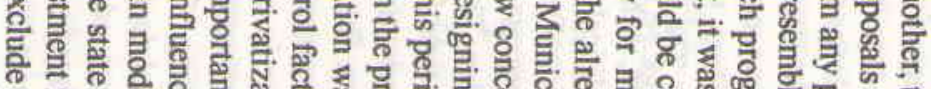

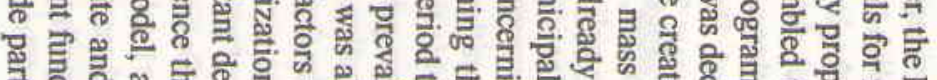
를.

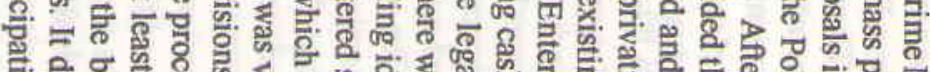

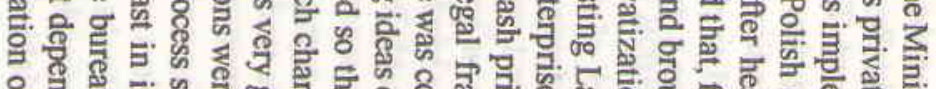

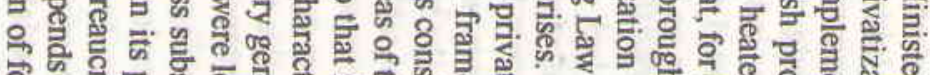

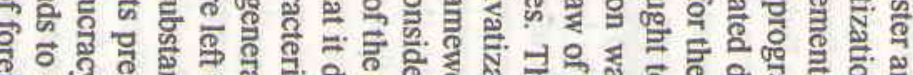

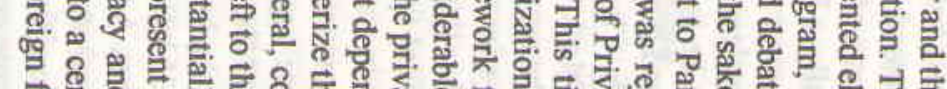

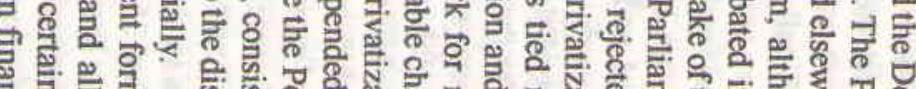

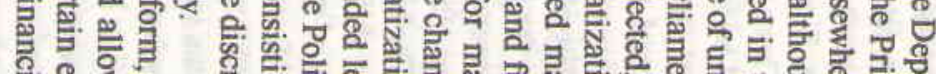

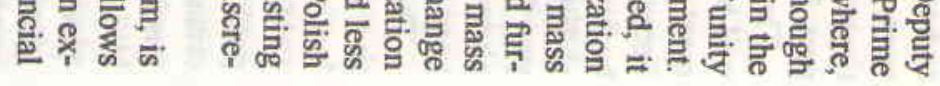

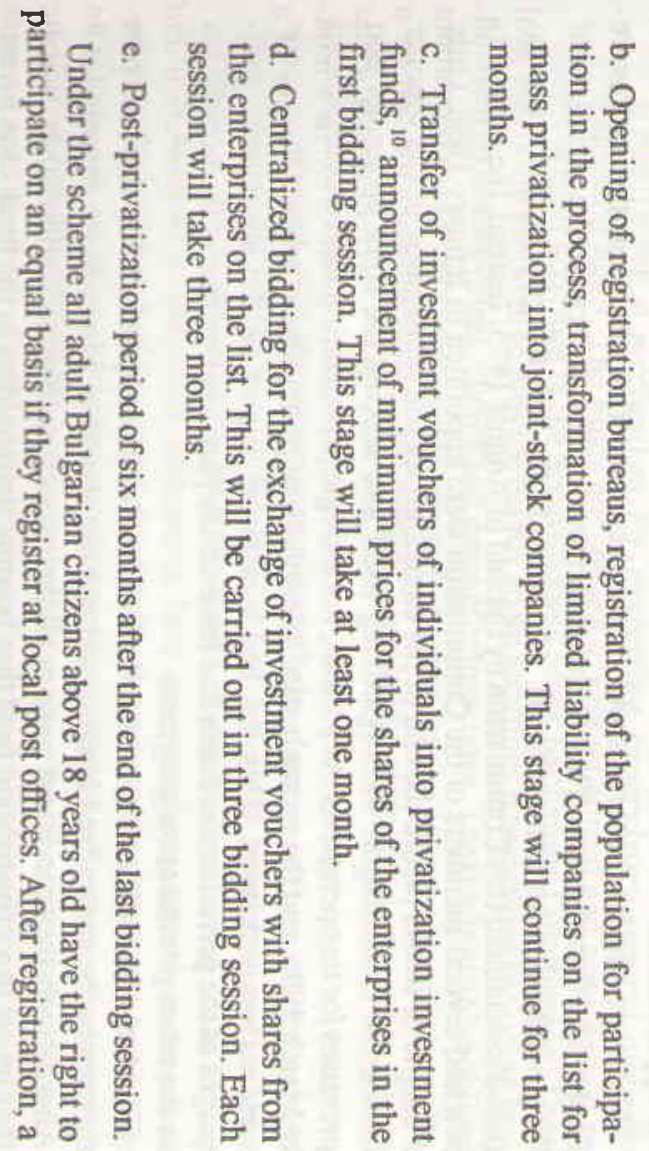

물. 을 뭉

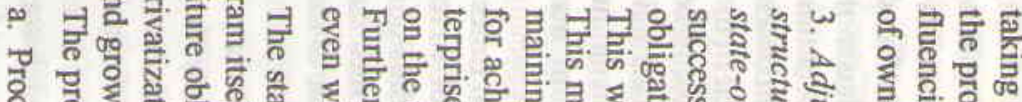

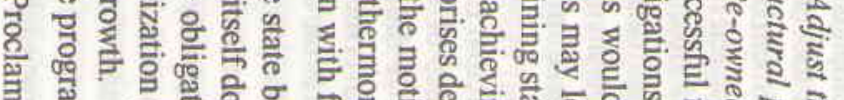

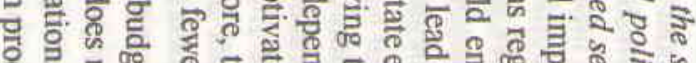

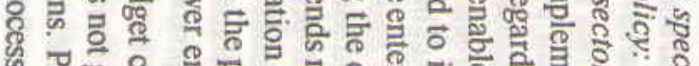

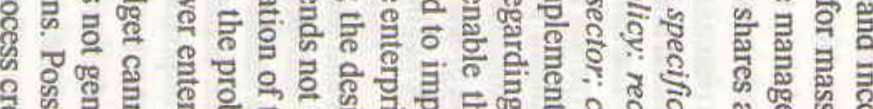

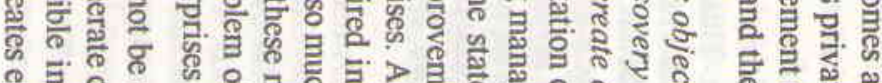
吉 8 \%

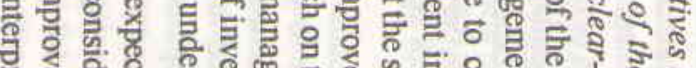
궁 융즁

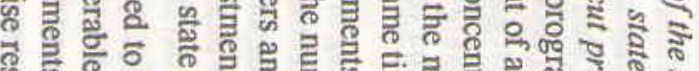

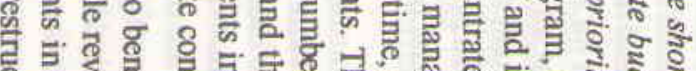

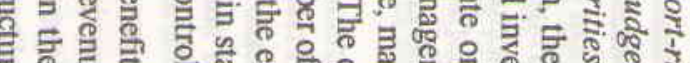
ร. § 홀을 品告

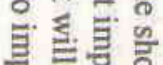
88 है 解瓶 홍ํำ

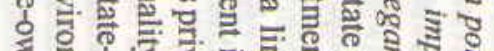

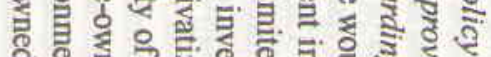
을

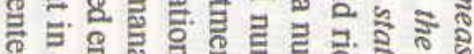
害.

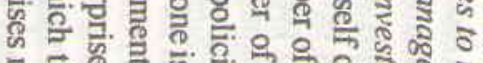

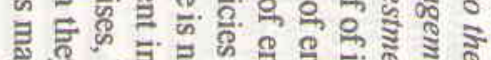
ํㅠㄹ

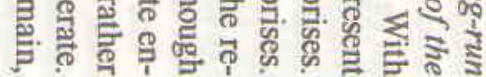

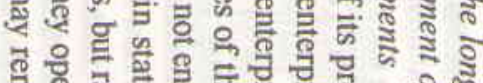

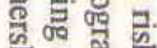
를

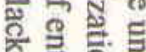
옹요 马를

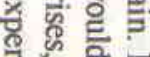

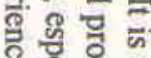
을. 질

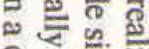
8 og. क्. टे ङ 常 롤 홍 () s. 응 을 항 识 롤 융 항․ㄹ 


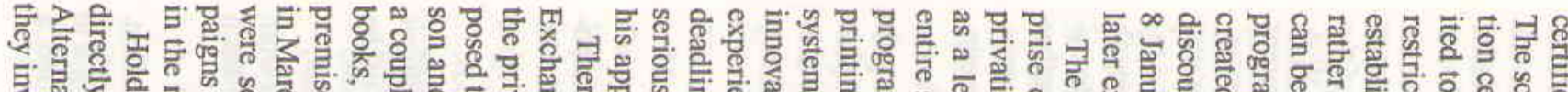

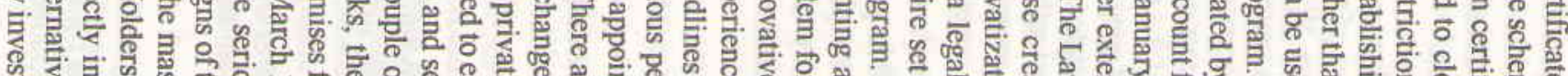

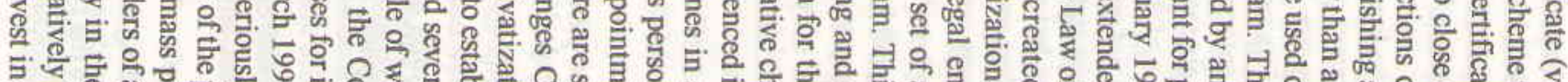

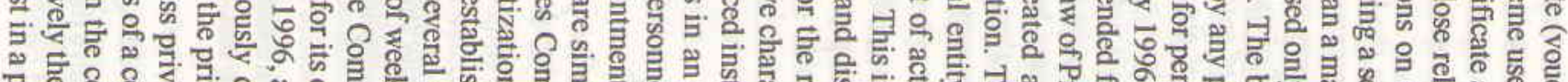

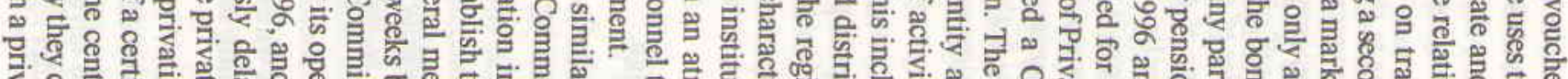

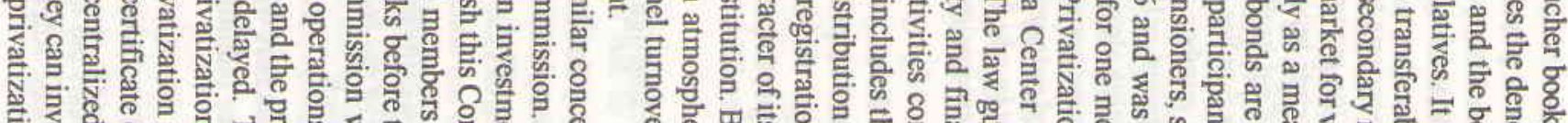
을.

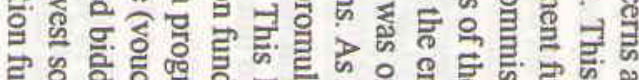

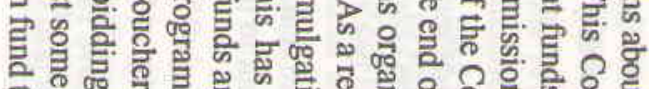

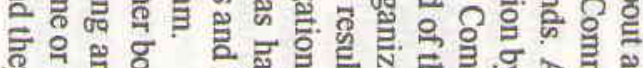

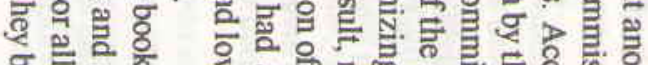

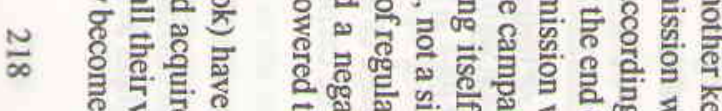

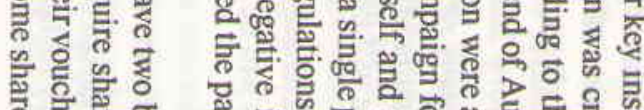

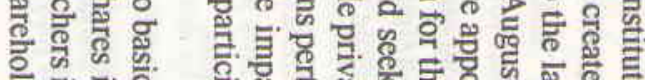

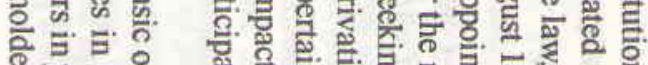

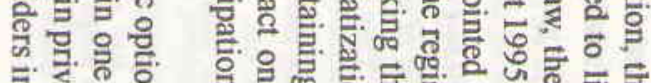

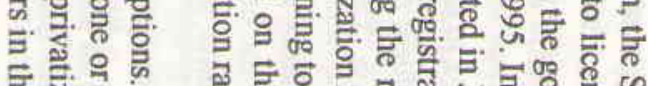
Е

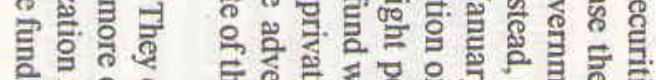

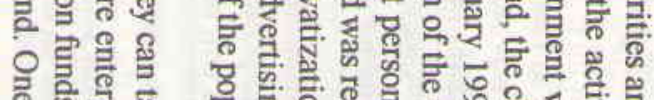

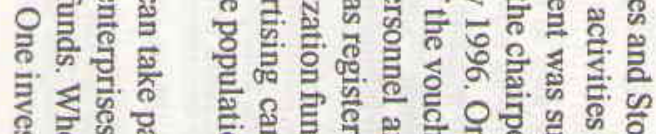

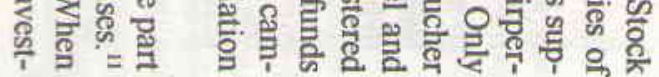
ळ $\forall$ ○े

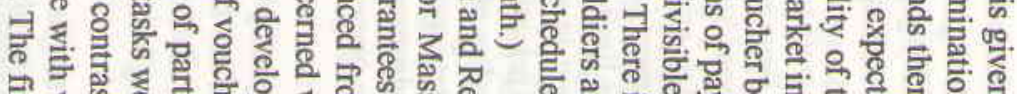

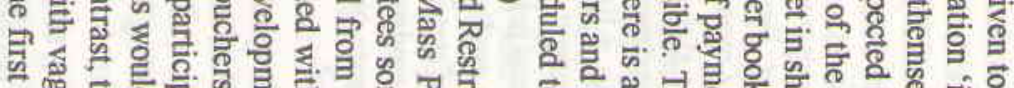

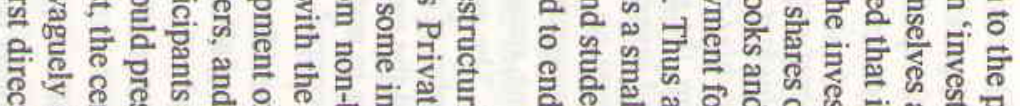

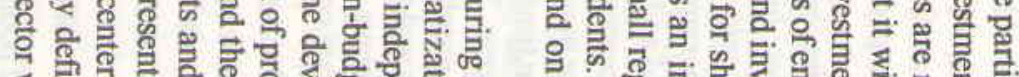

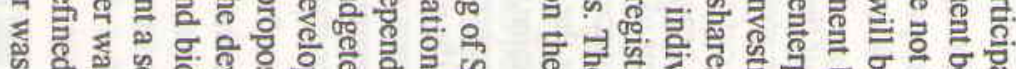

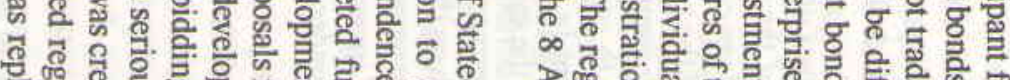

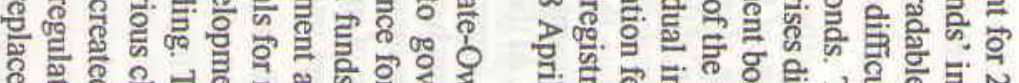

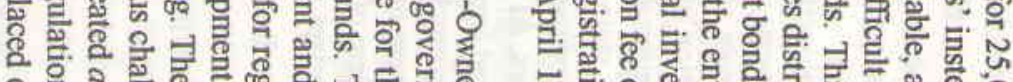

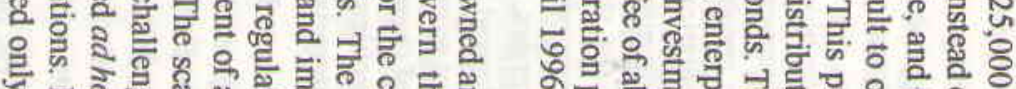

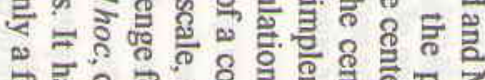

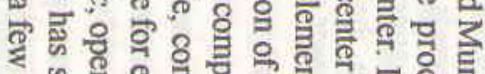

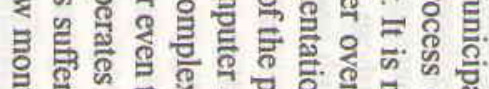

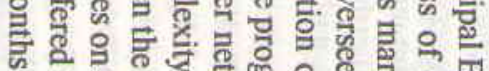

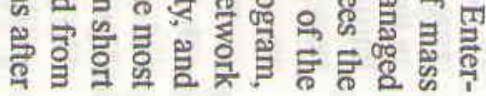

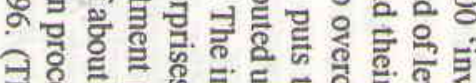

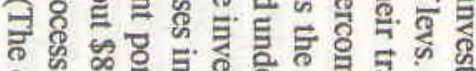

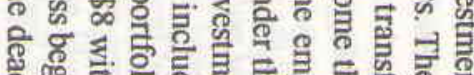

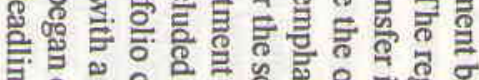

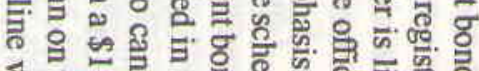

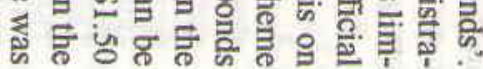

ํㅡㄹ 총ํำ

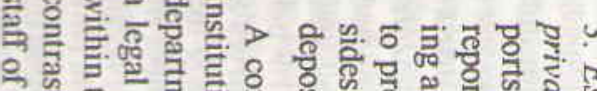
के इ

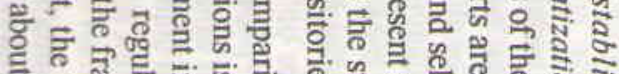

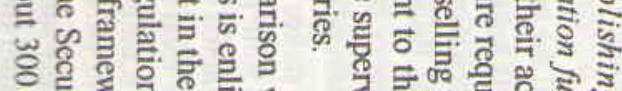

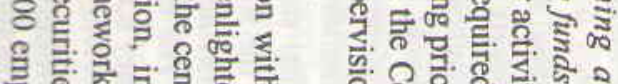

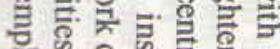
응을 흘 ते

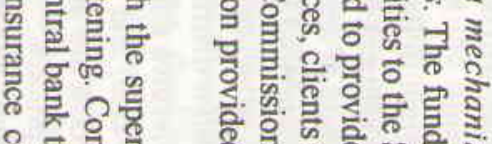
웃 $8 \hat{\mathrm{F}}$ 일

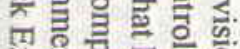

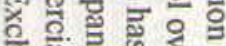

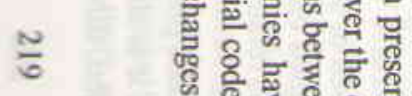

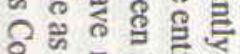
을

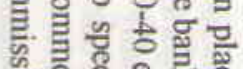

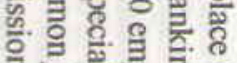
․ㅡㅇ 름ㅎํㅇ 홀

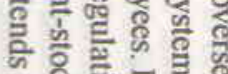

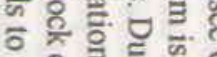

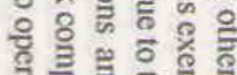

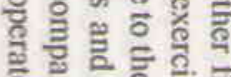
(1)

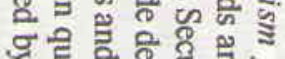

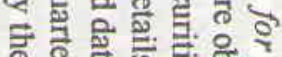
용 क क

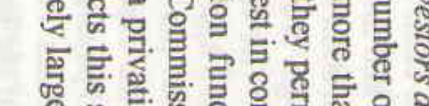

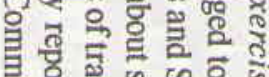
.

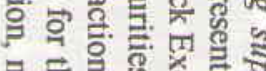
击

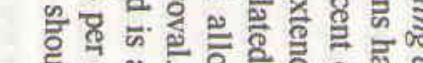

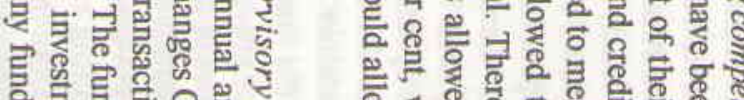

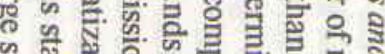

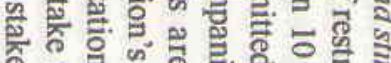
ธ०

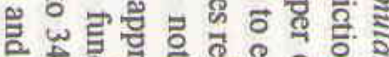

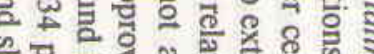

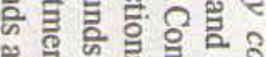

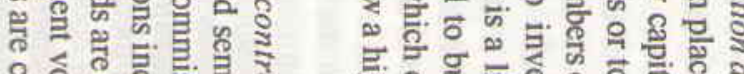
哭 8 ํㅕㄹ

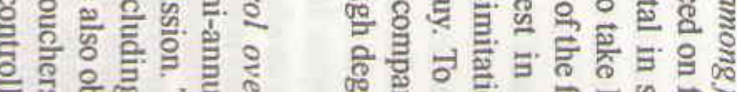

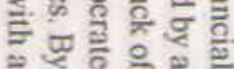

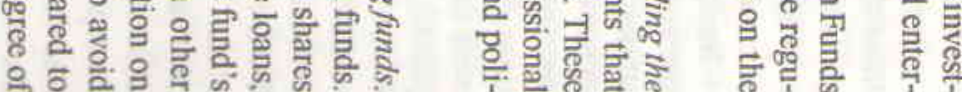

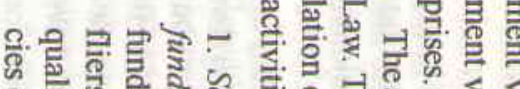

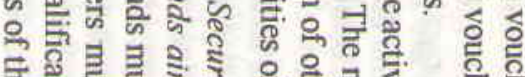
है ०.

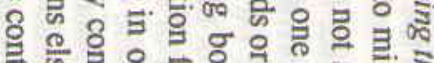
织。

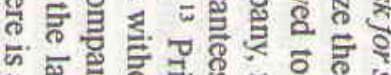

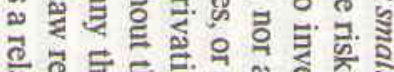

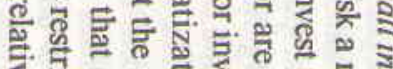

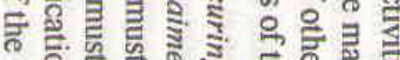

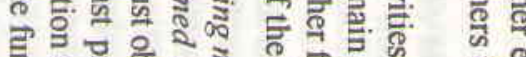

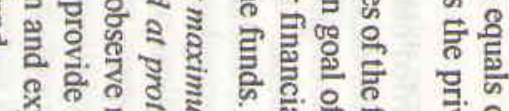

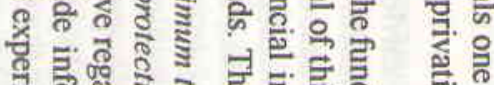

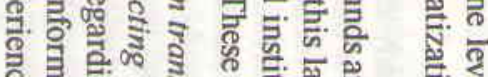

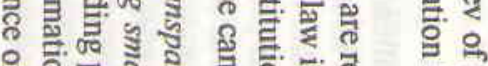
을 흘

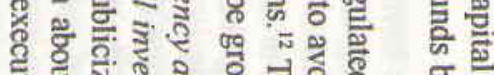

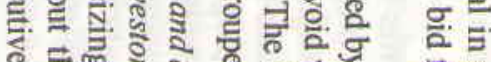

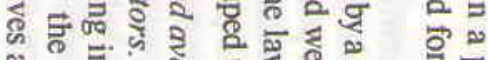

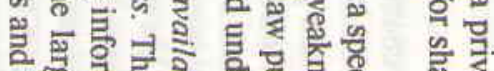

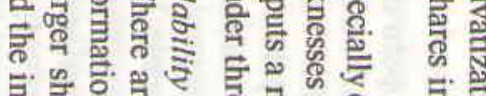

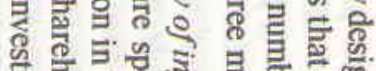

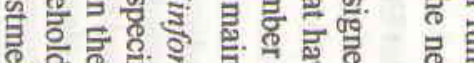

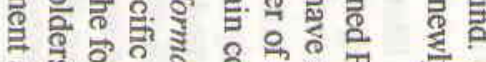

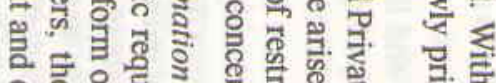

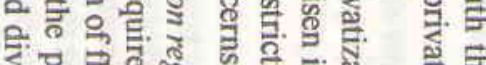

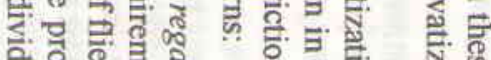
总串 


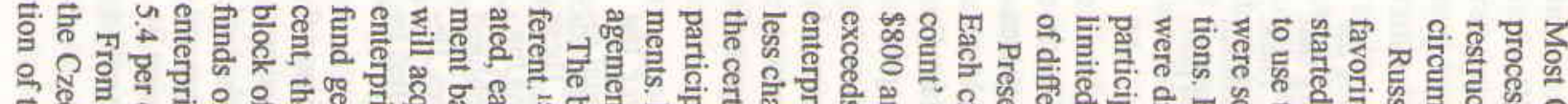

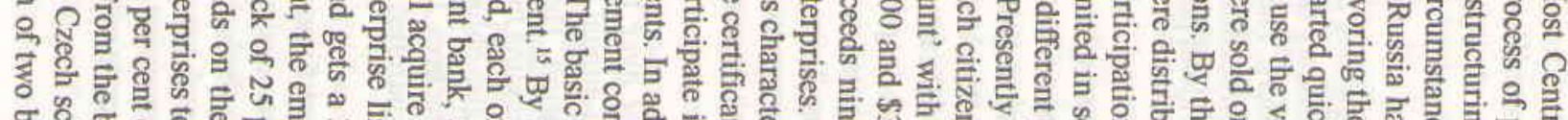
mong

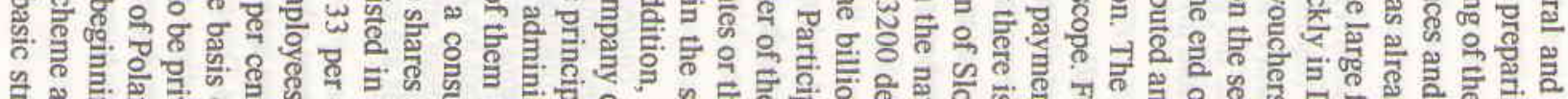

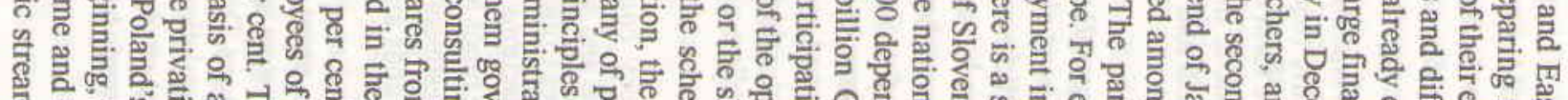
Wh an

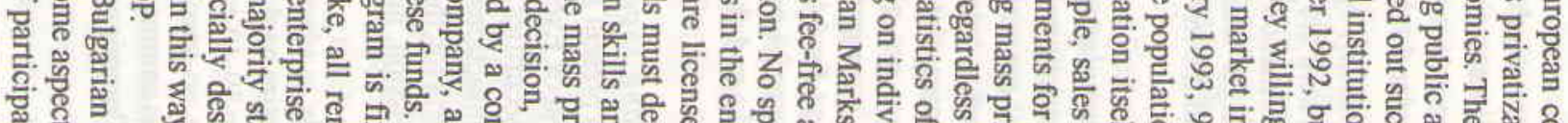

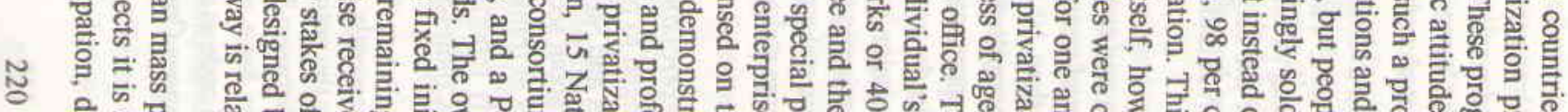

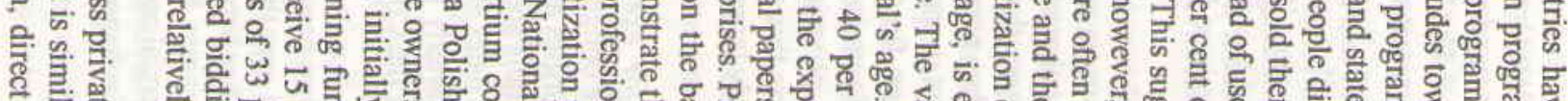

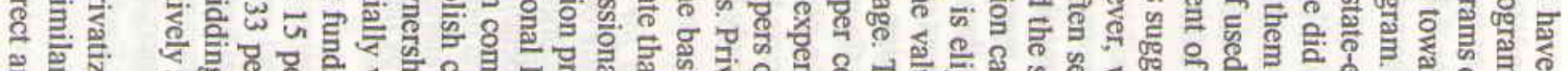

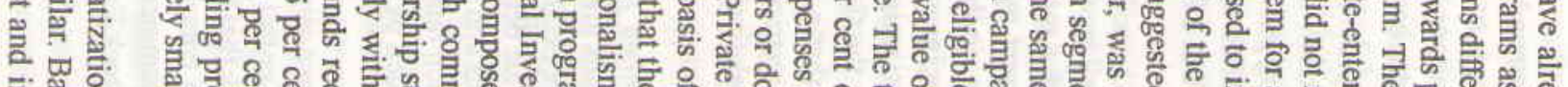

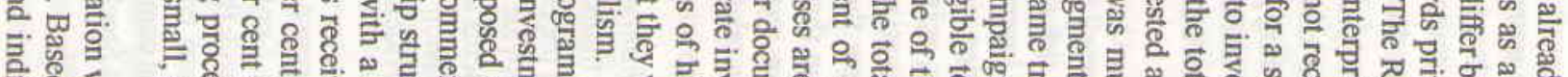

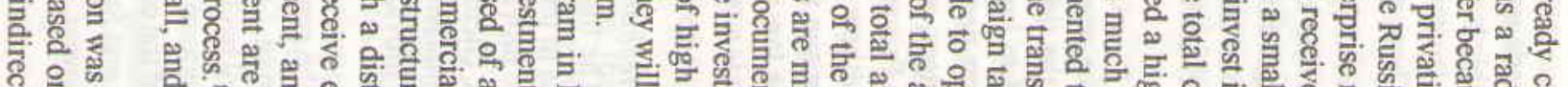

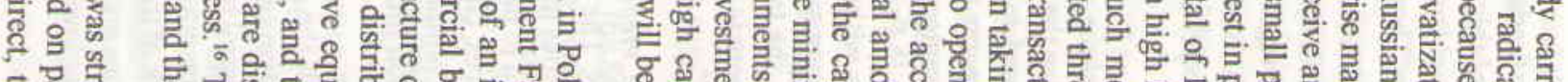

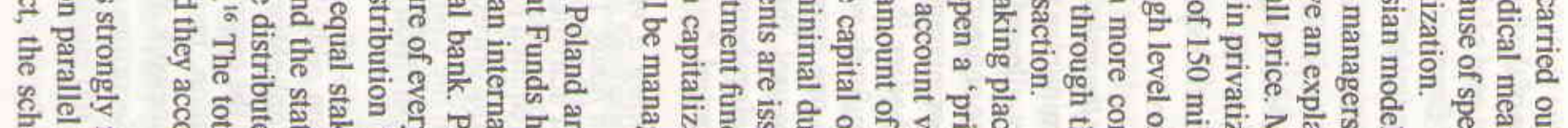

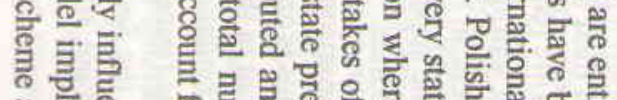
范范

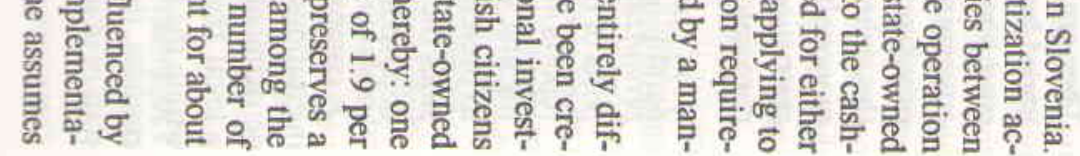

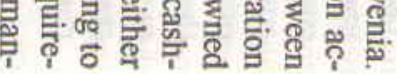

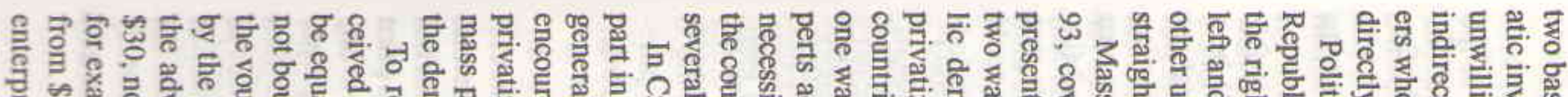

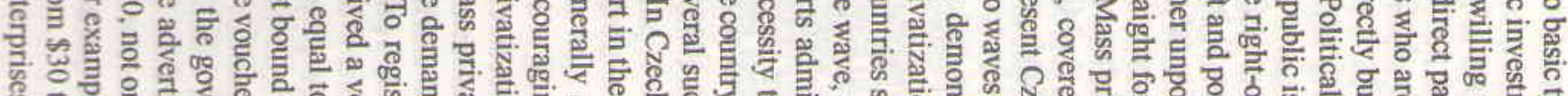

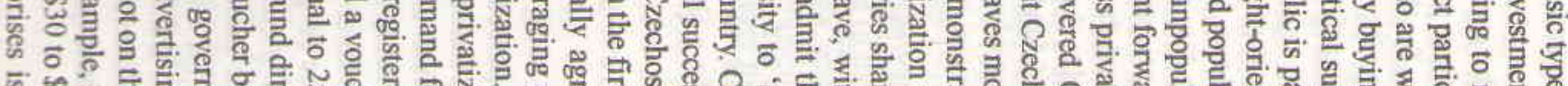

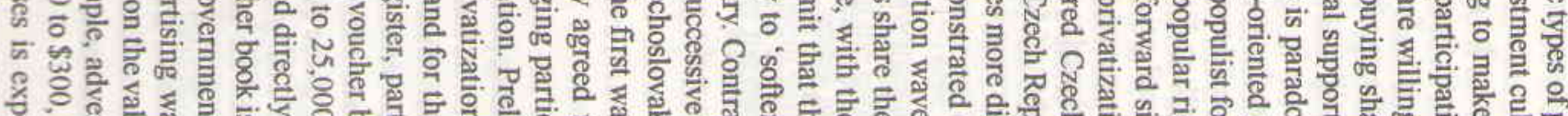

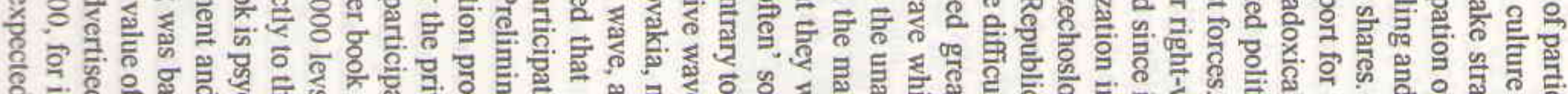

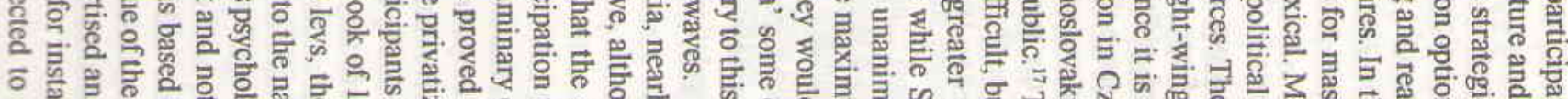

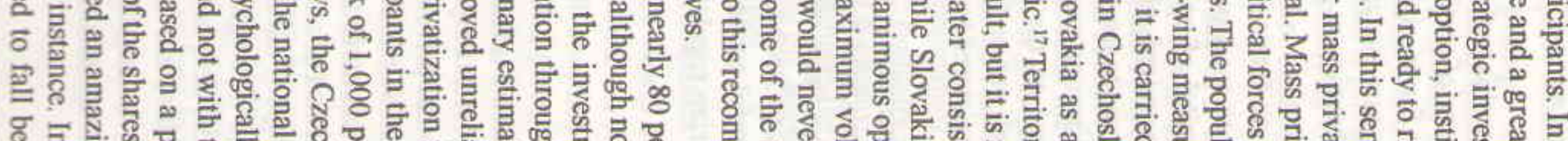

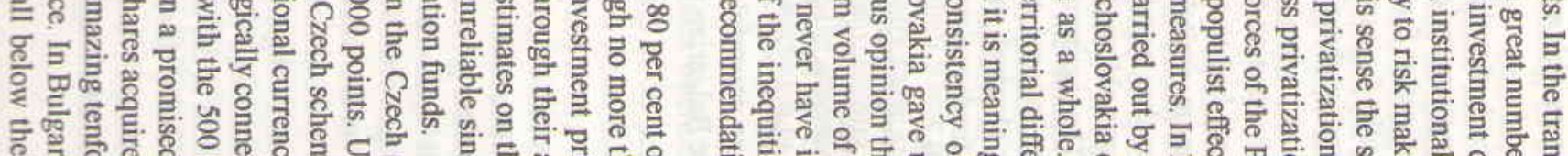

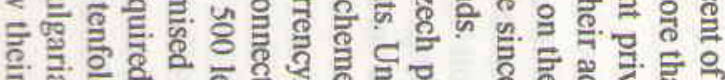

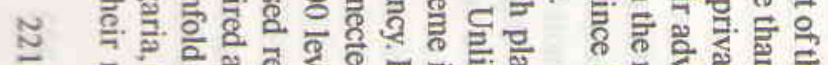

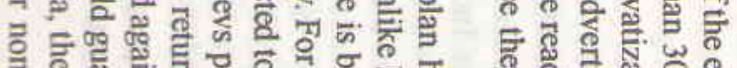

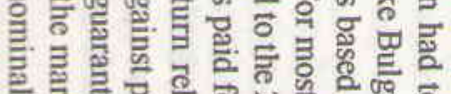

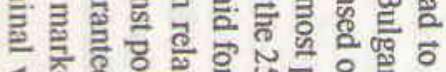

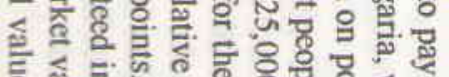
言 실

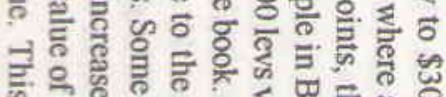

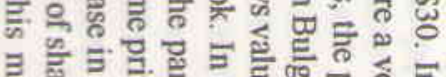

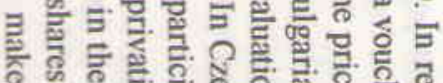
a

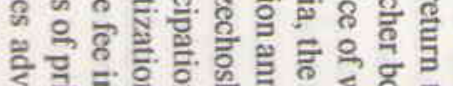

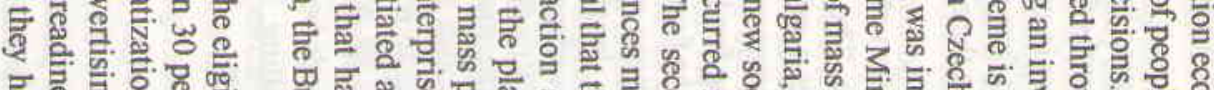

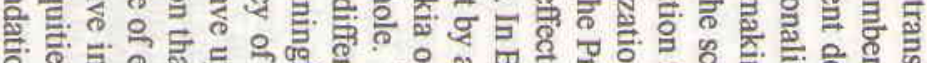

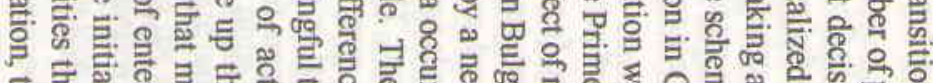

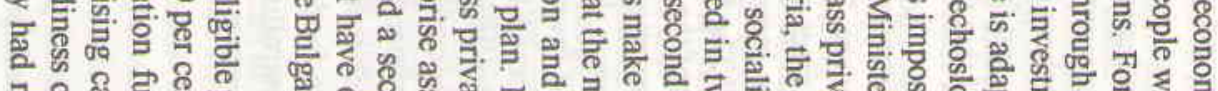

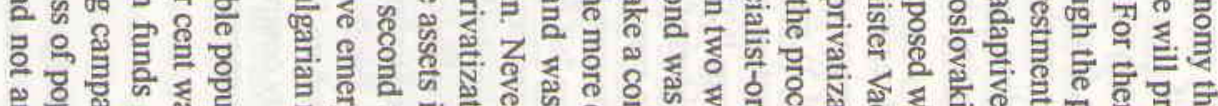

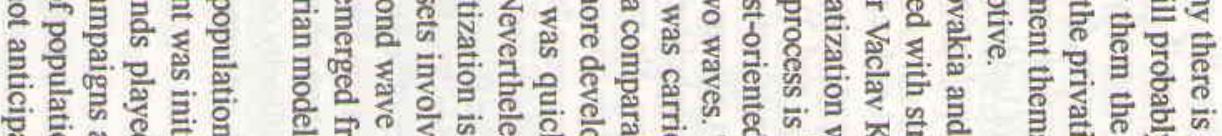

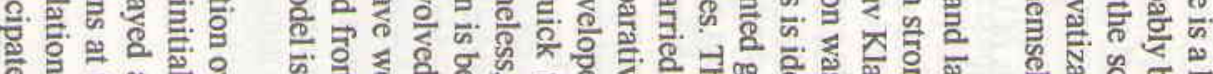

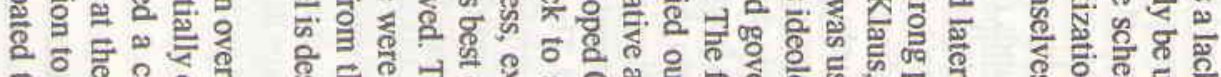

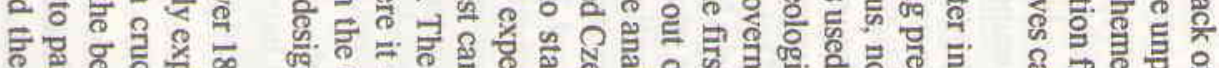

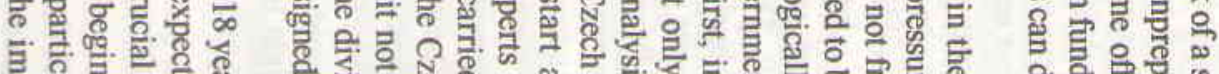

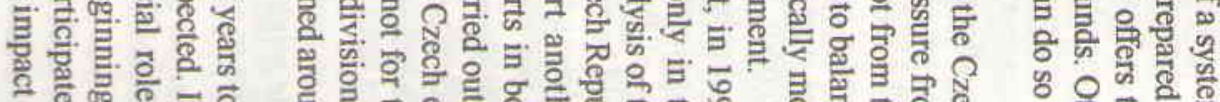
1)

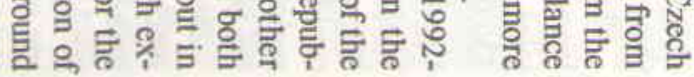

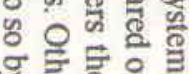


틀ำ

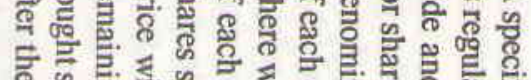

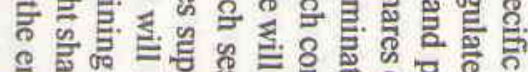

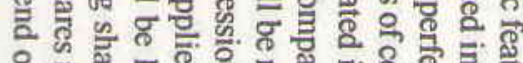

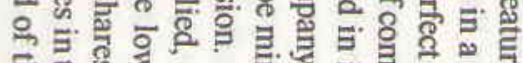
En

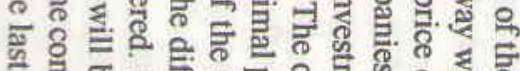
$8=5$

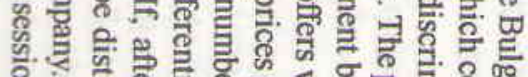

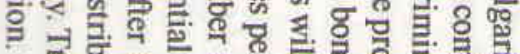

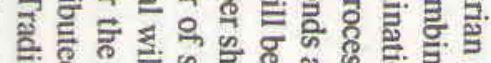

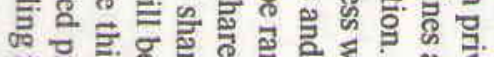

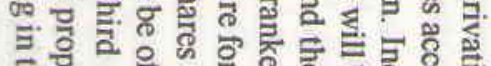

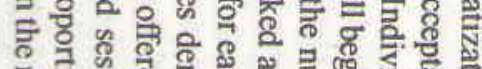

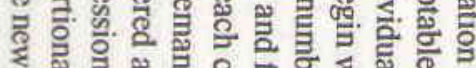
in

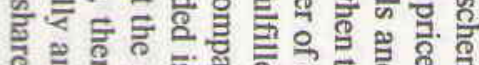

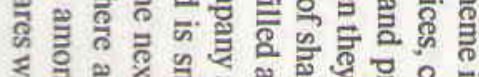
Int

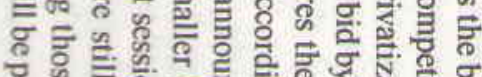

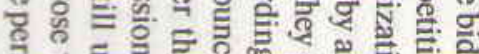
In to (n)

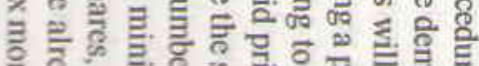

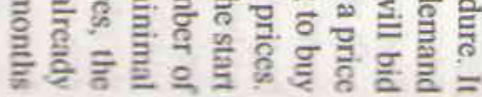

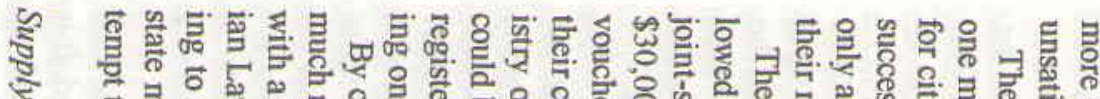

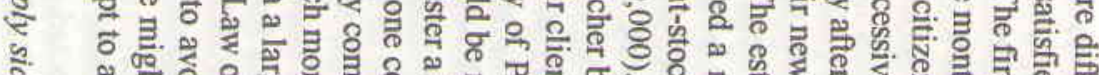

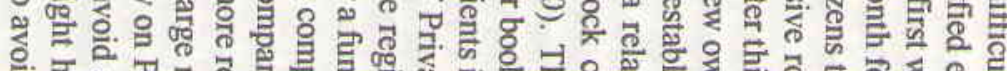

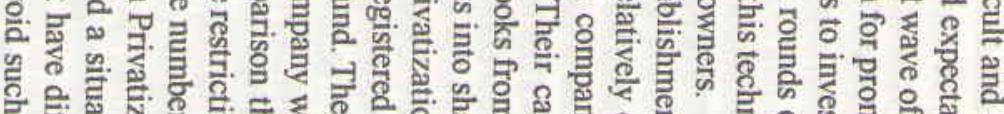

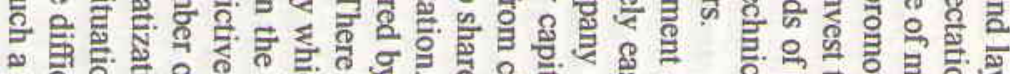

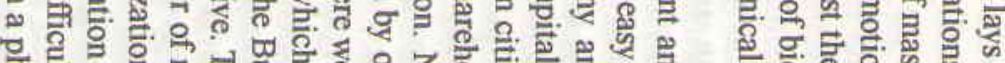

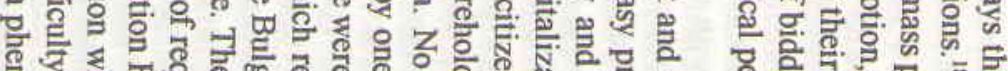

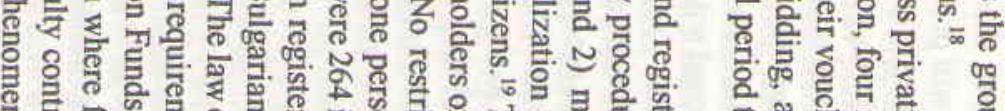

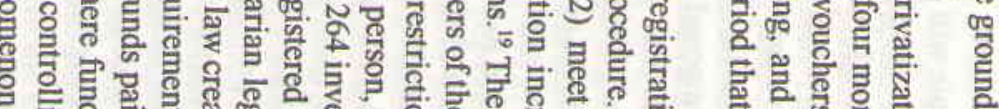

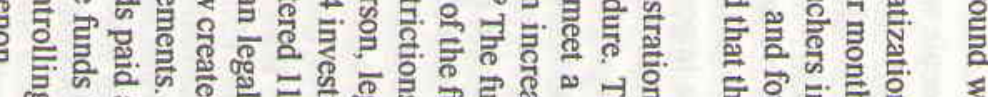

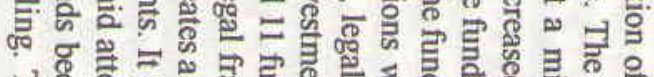
$\forall$ 유유.

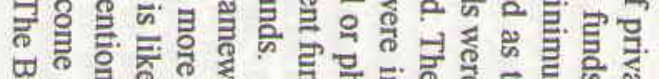
to. 을 듕 के

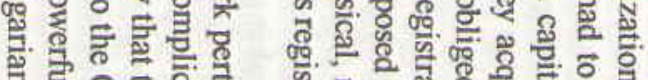

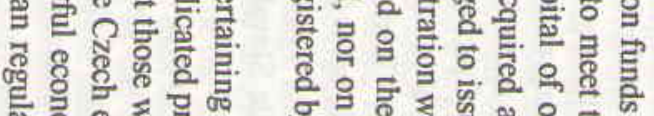

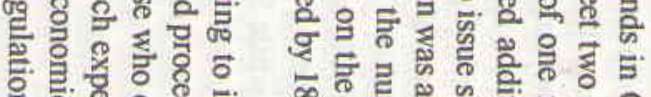

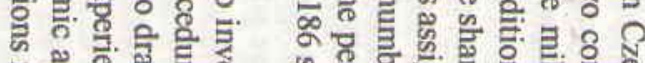

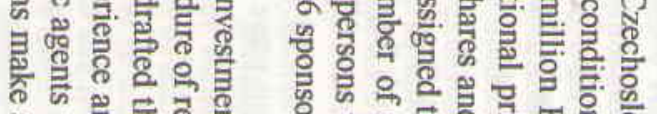

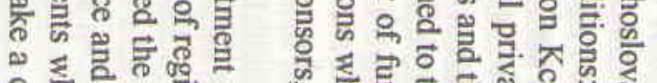

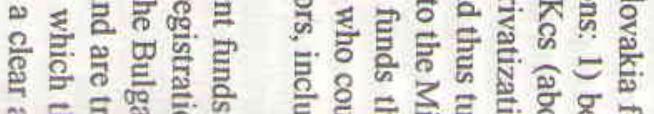

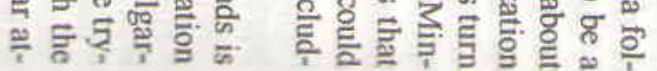

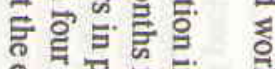

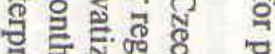

है.

을

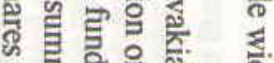

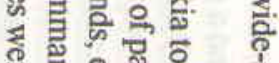

है ․ㅗㅇ. 일

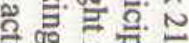

= 政

है을

施

क्ष

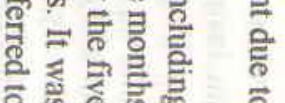

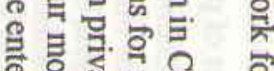

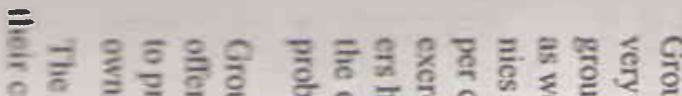

竞言

틀 을

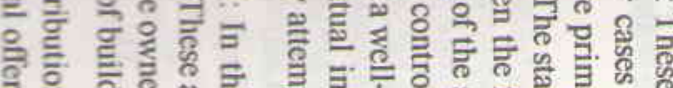

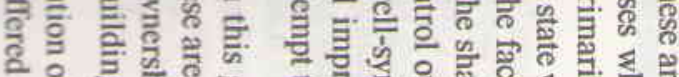

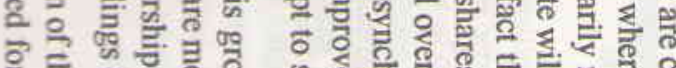

ま

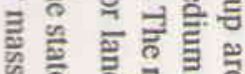

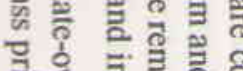

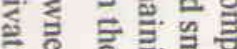

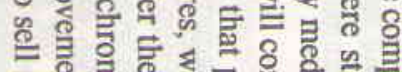
है

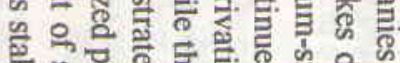

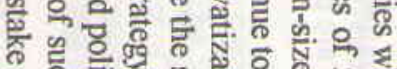

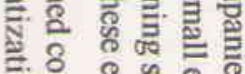

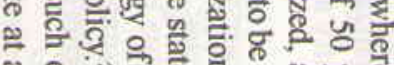

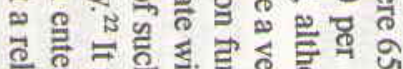

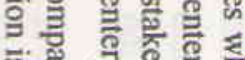

फ.

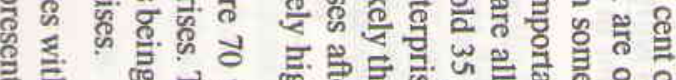

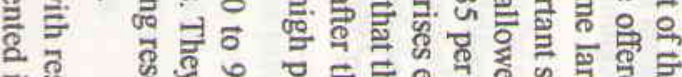

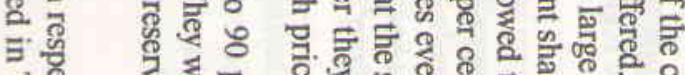

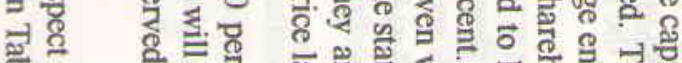

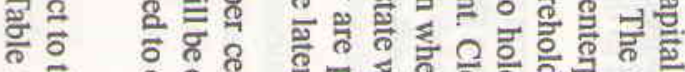

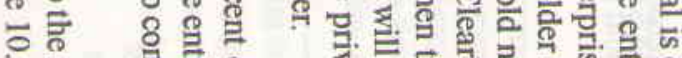

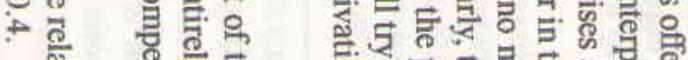

屏. 象

के के

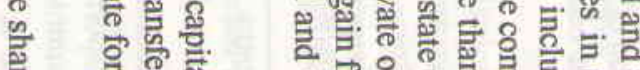

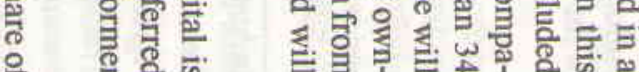

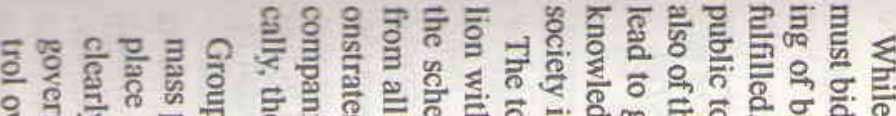

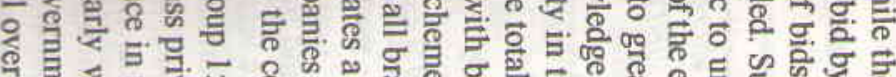

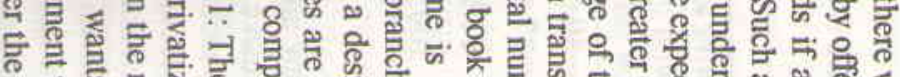

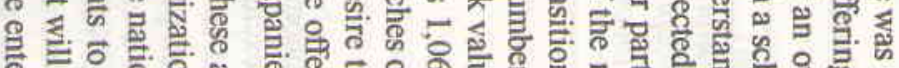

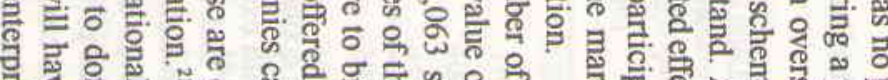
ह

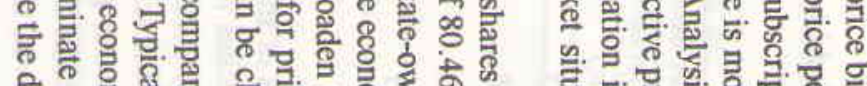

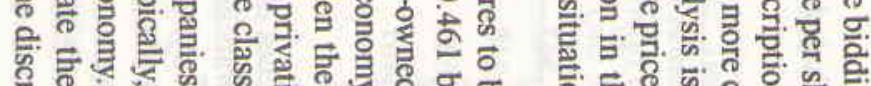

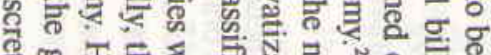
등일.

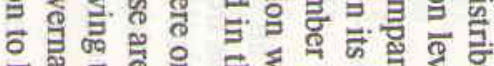
흣 है

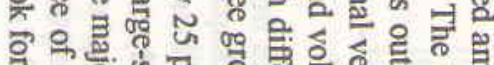

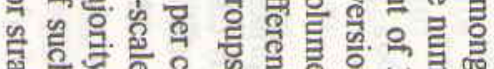
둥

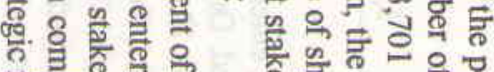

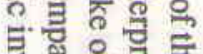
क्ष

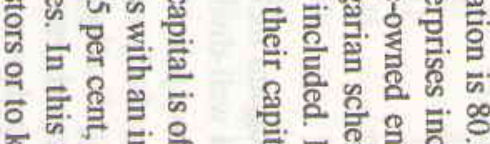

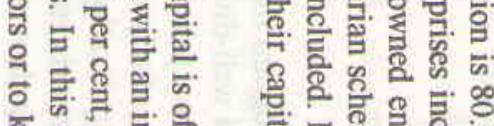

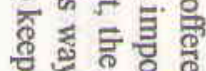

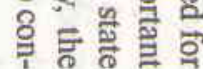

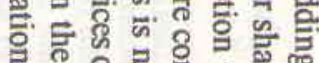

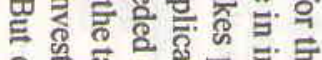

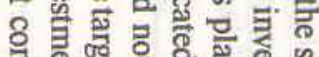

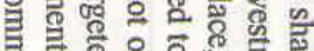

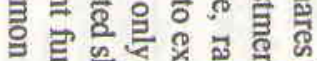
敦窟。

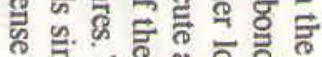

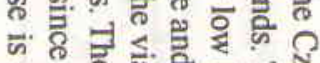

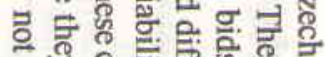

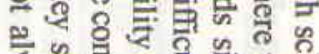

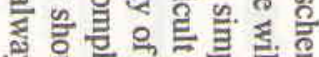

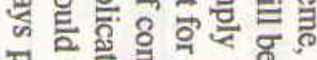

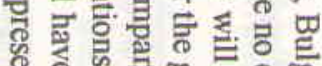

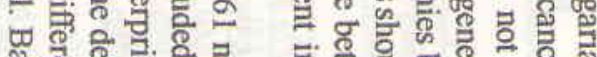

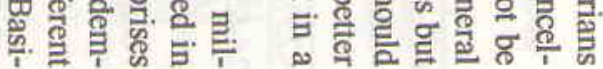

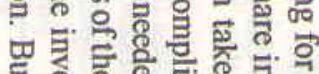

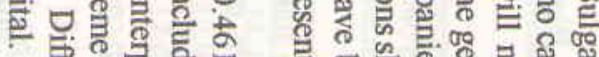




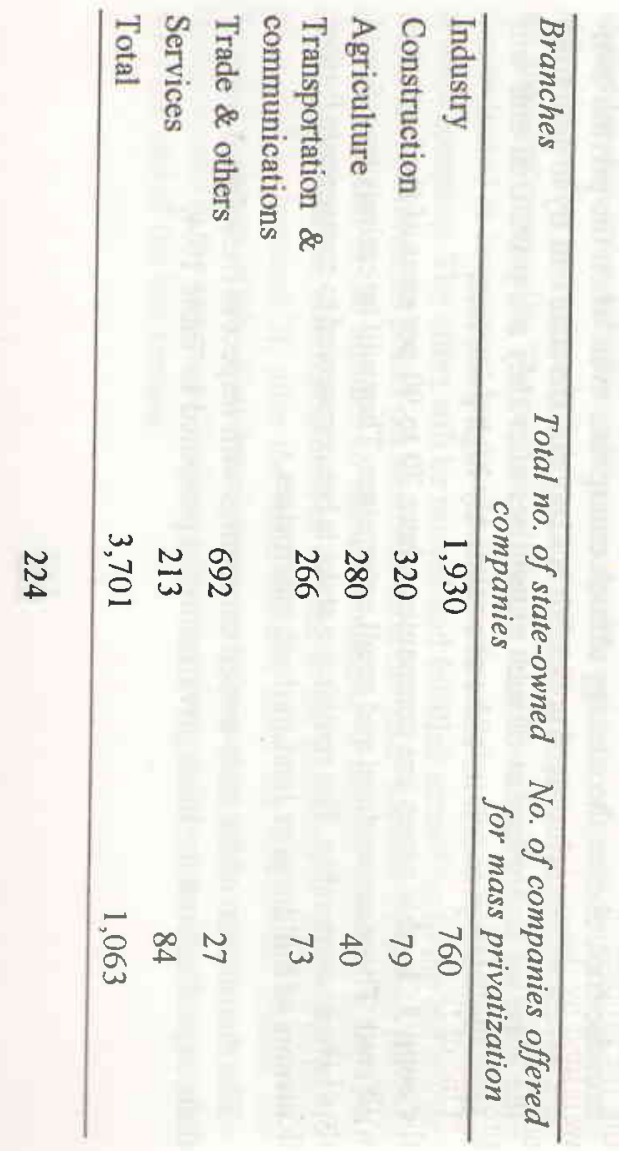

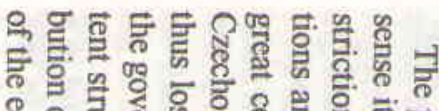

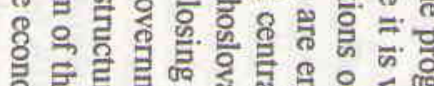

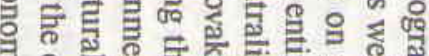

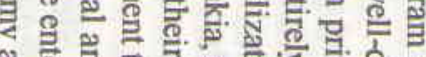

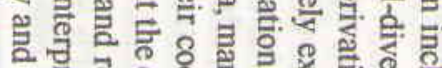

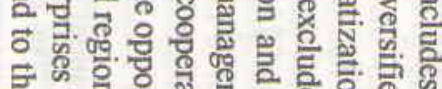
\%

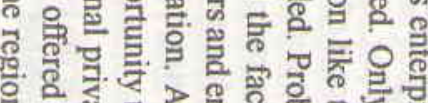

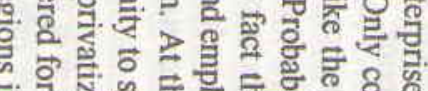

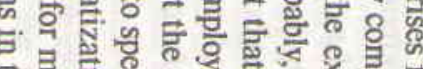

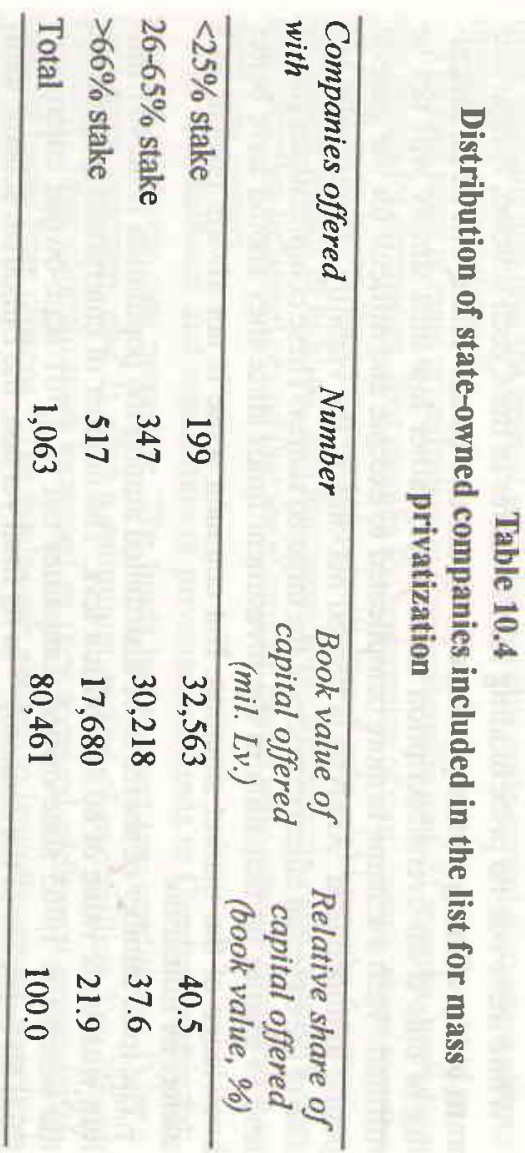

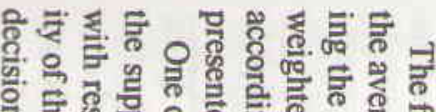

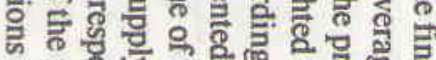

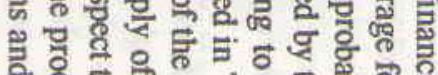

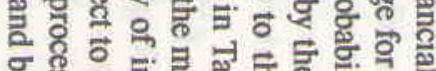
С

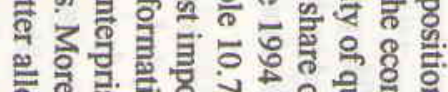

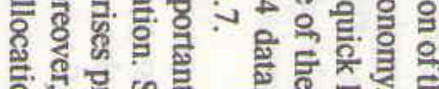

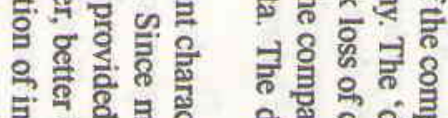

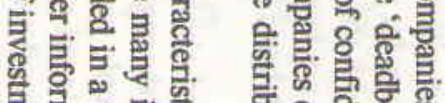

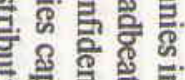

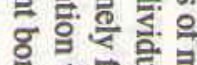

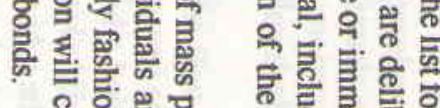
을 흘

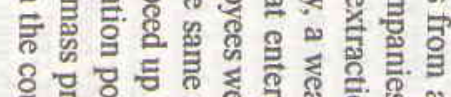

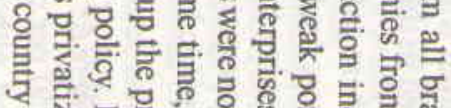

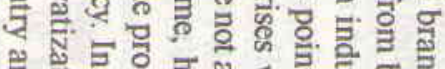

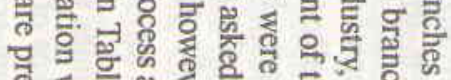

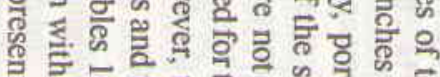
范

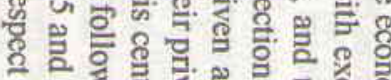
ธ。 引

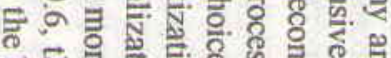

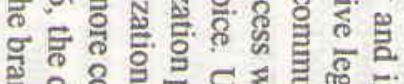

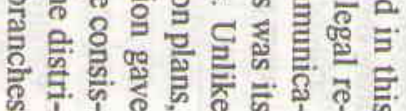

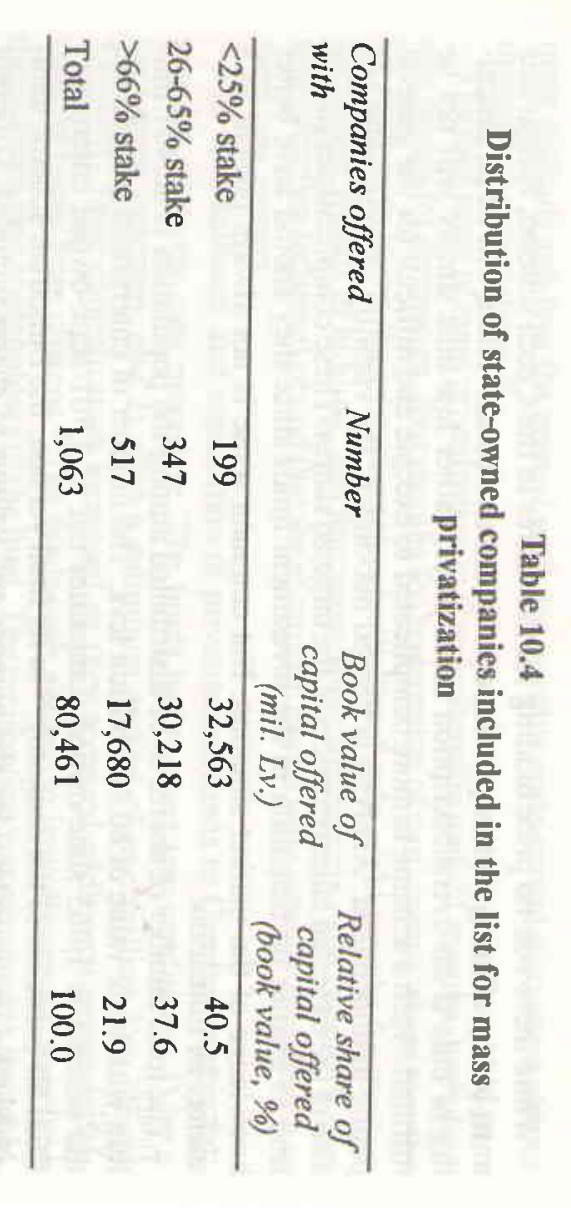

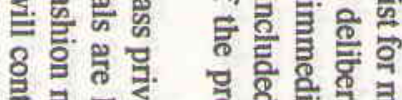

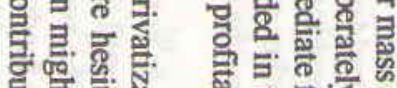

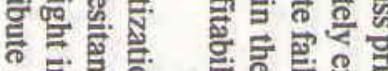
के \% \% \& क्षृ

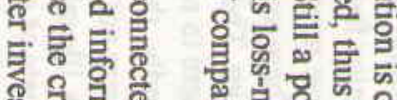

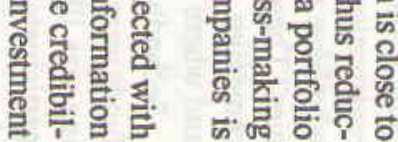

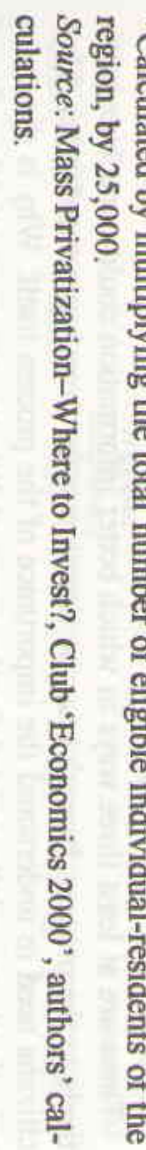

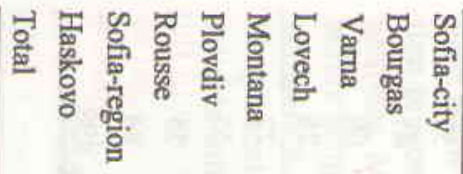

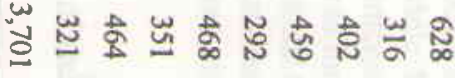

可

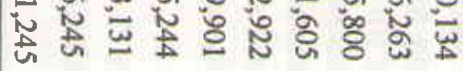

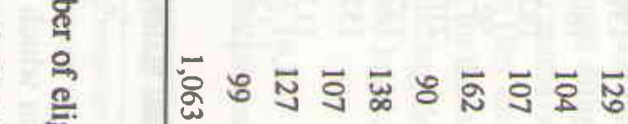

ङ ํํำ

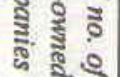
娄密

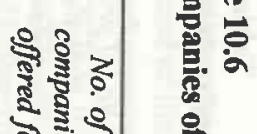

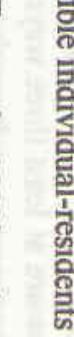

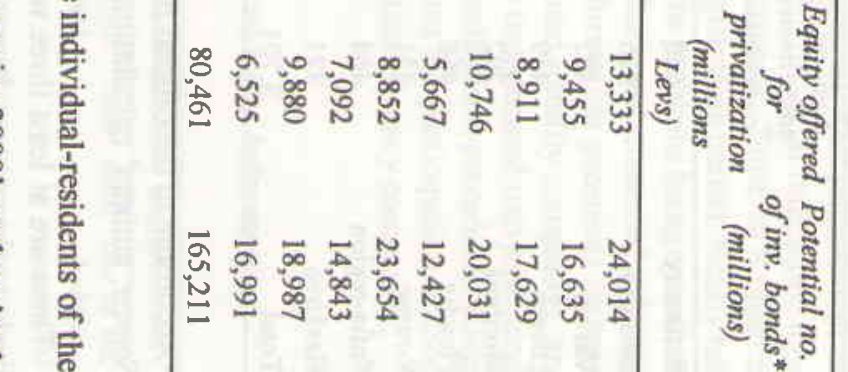




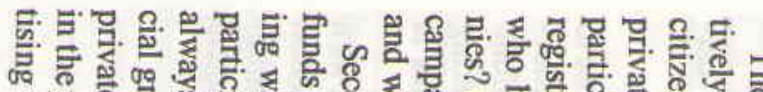

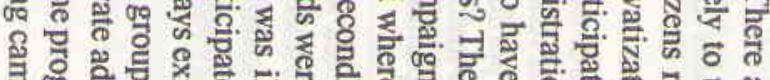
害嵒

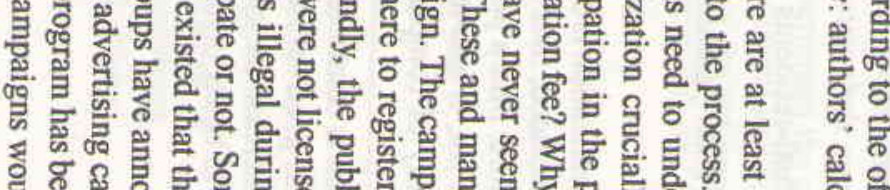

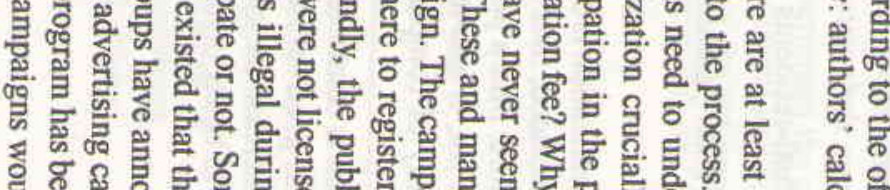

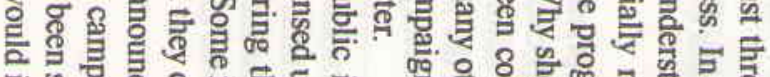

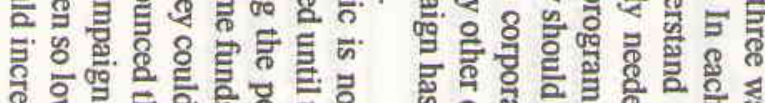

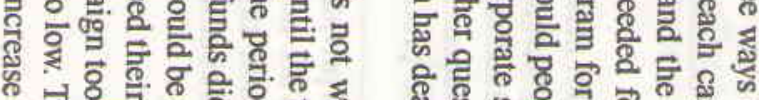

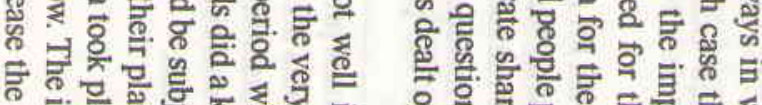

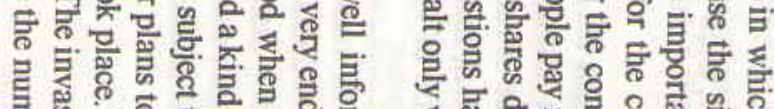

₹ 영

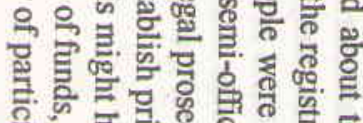

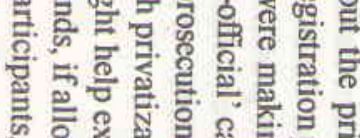

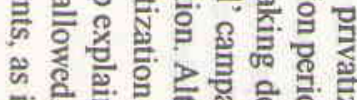

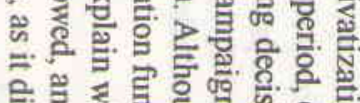

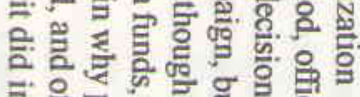

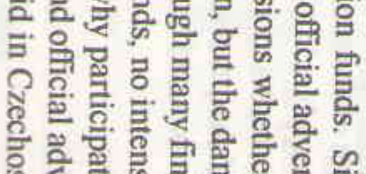

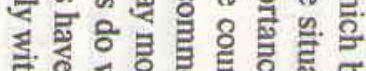

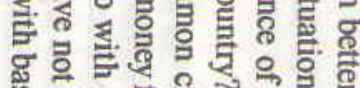

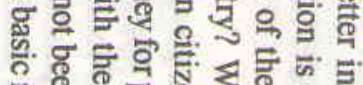
政

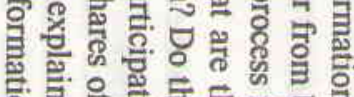

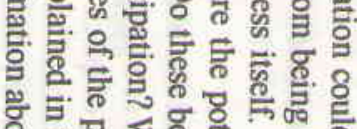
늘

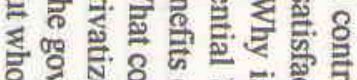

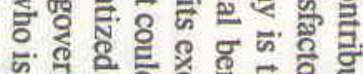
5

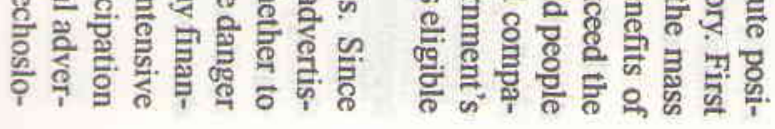

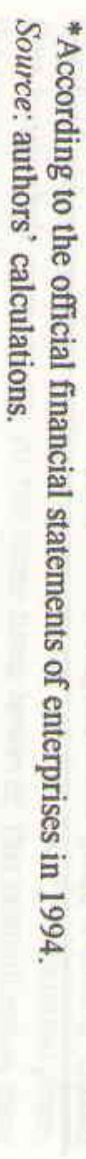

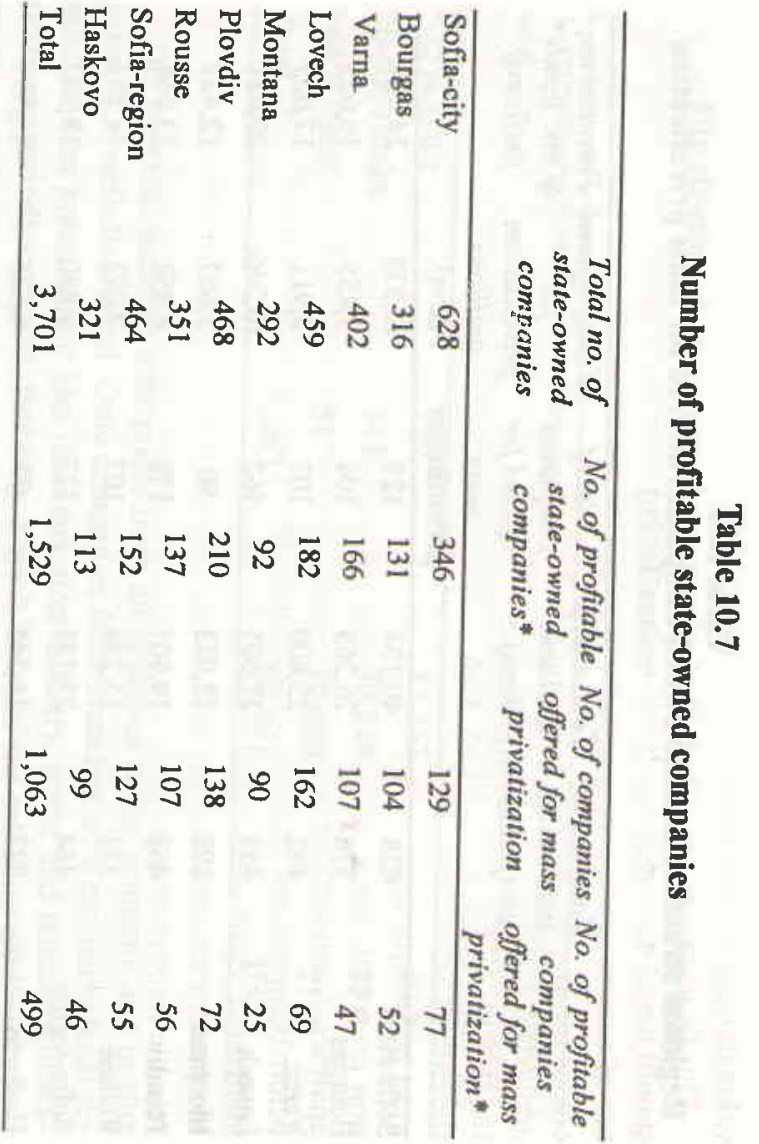

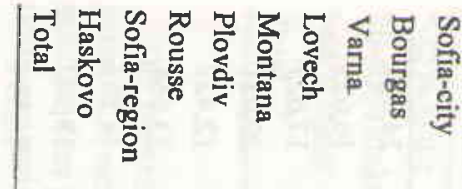

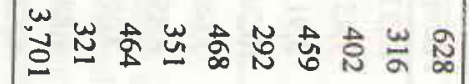

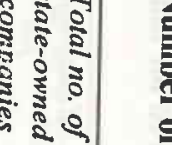

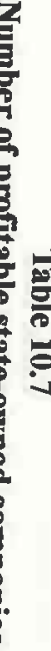

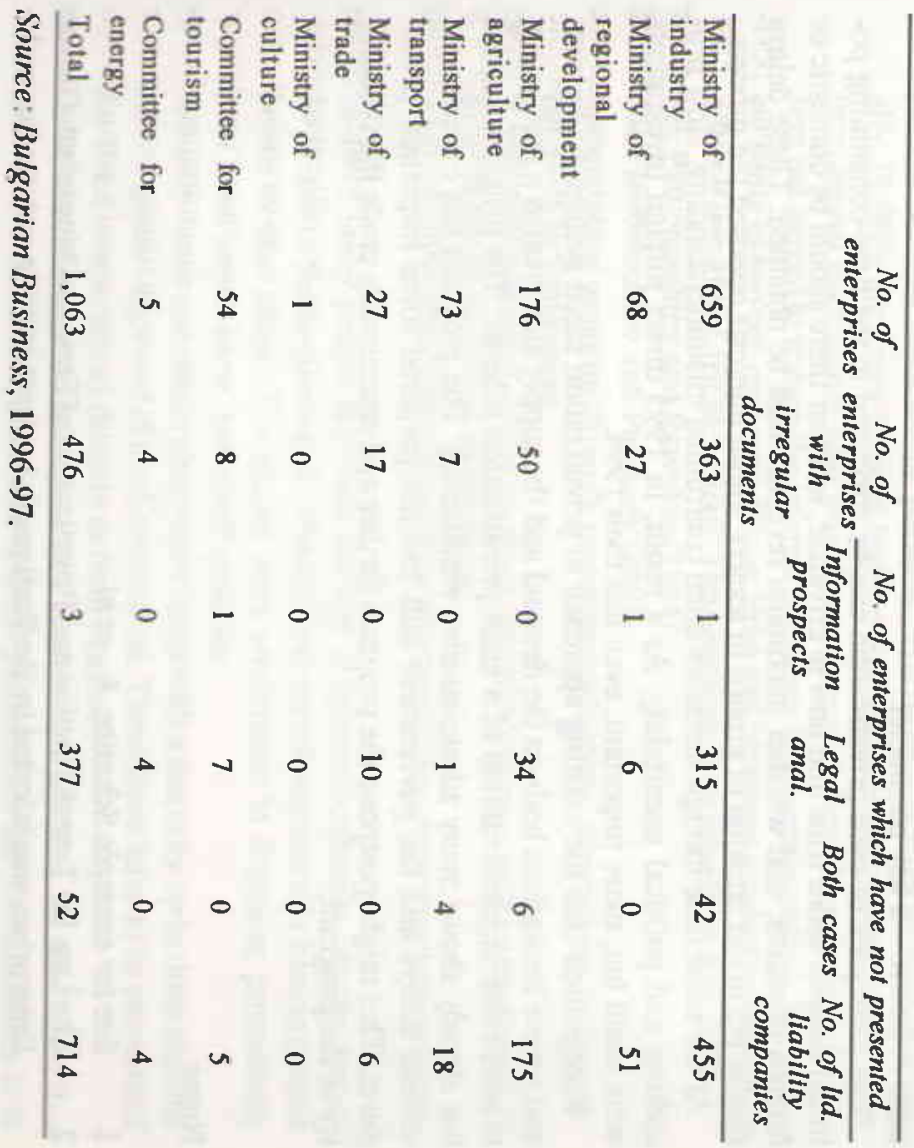

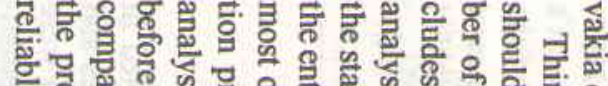

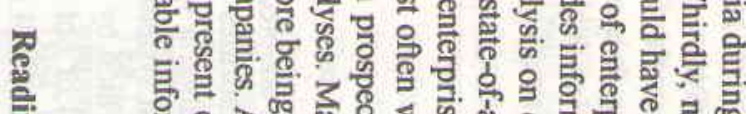

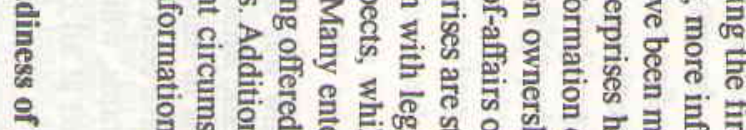

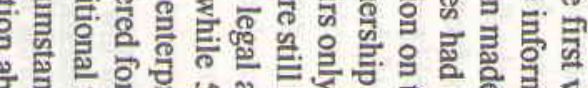

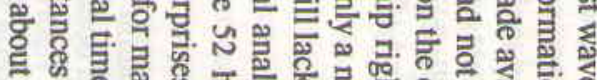

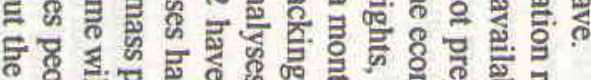

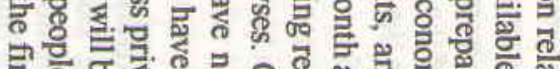

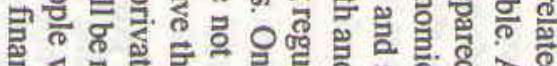

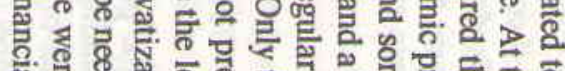

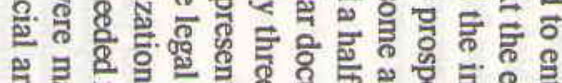

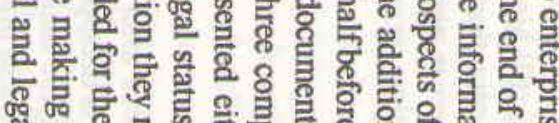

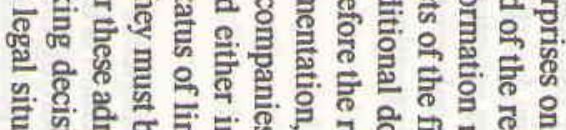

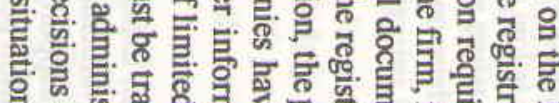

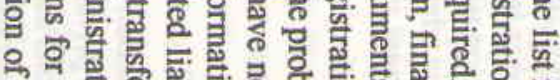

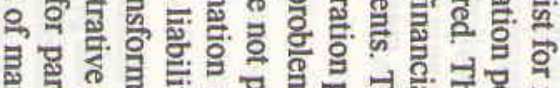

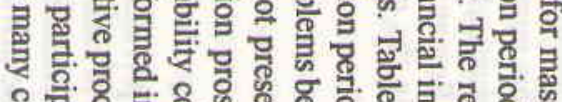

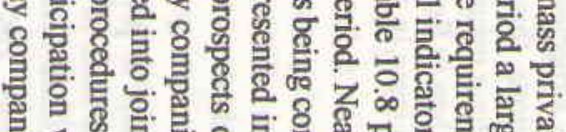

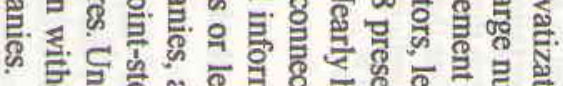

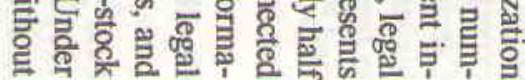




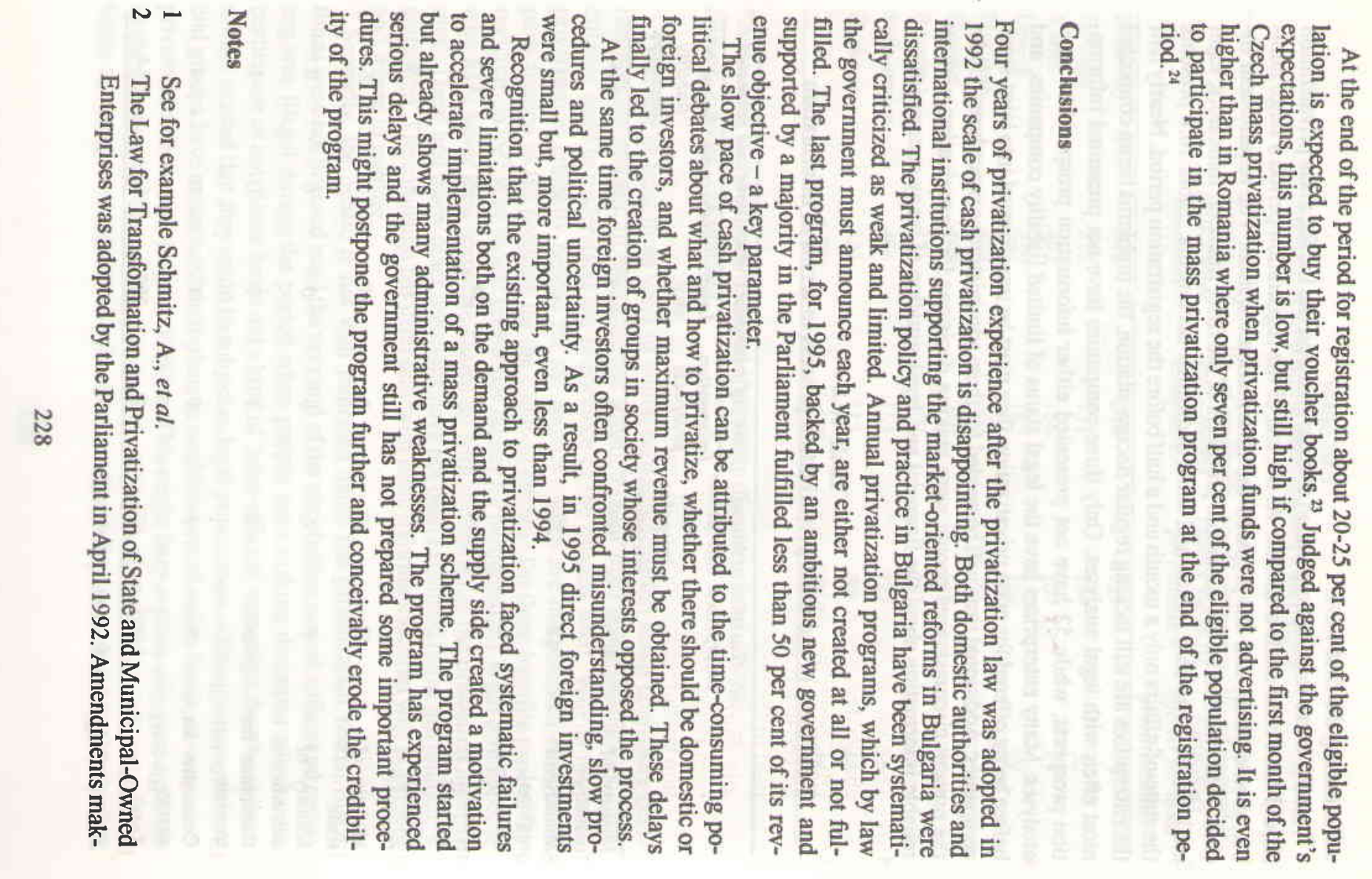

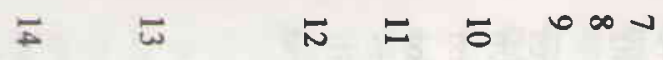

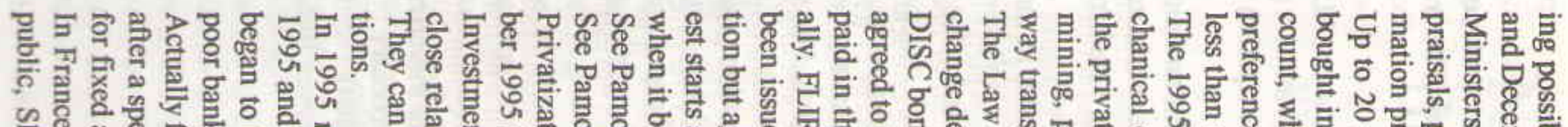

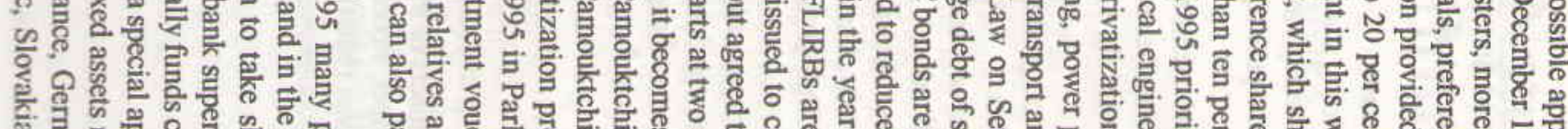

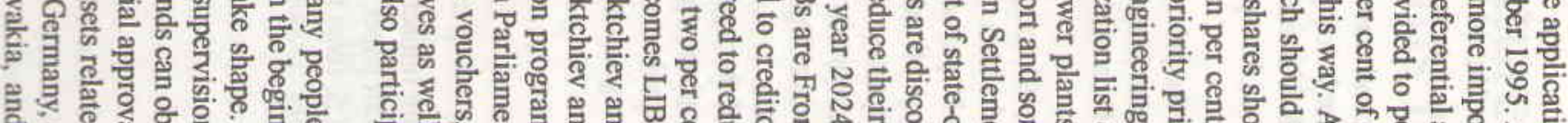

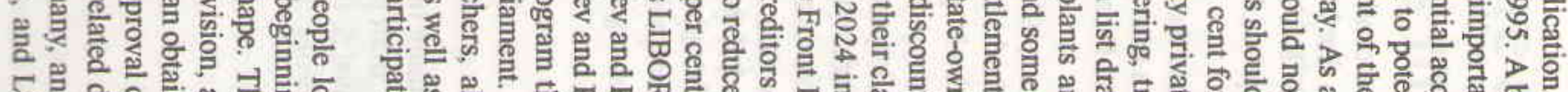

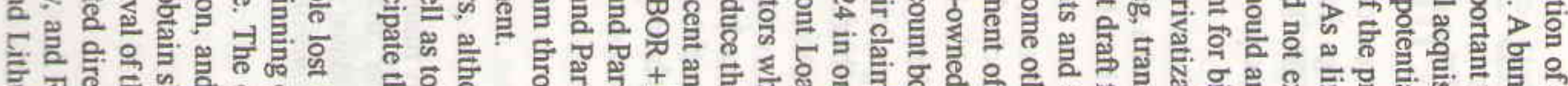

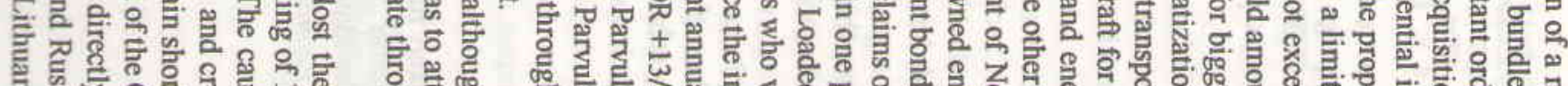

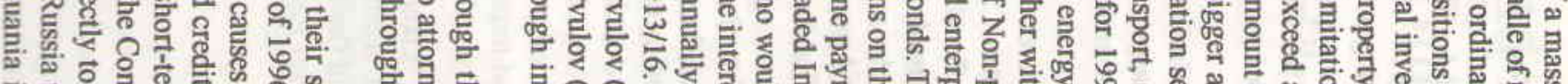
:

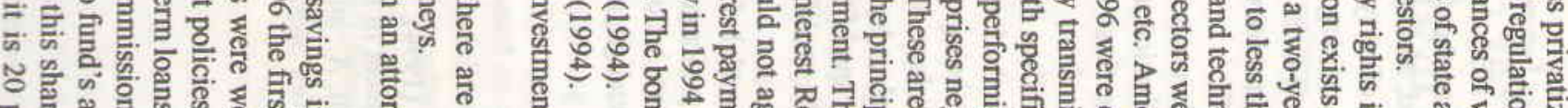

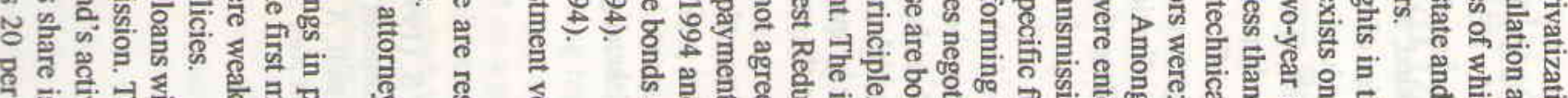

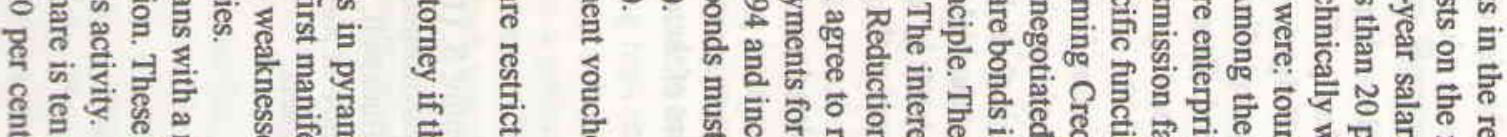
: 을.

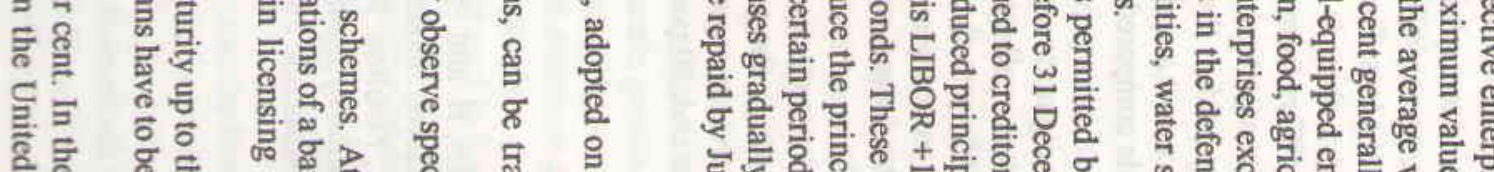

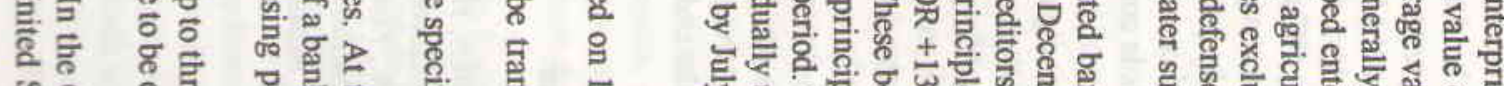

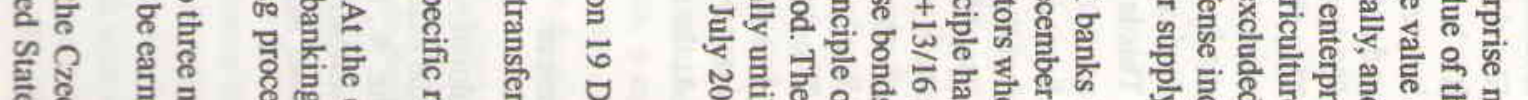

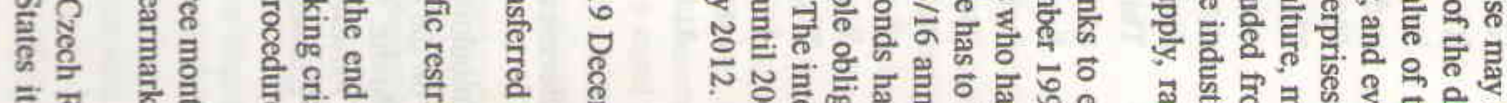
를 을 을

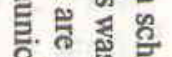

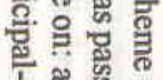

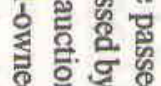

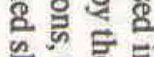
क् 究产市 ㅍ. 응

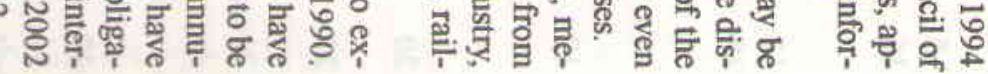




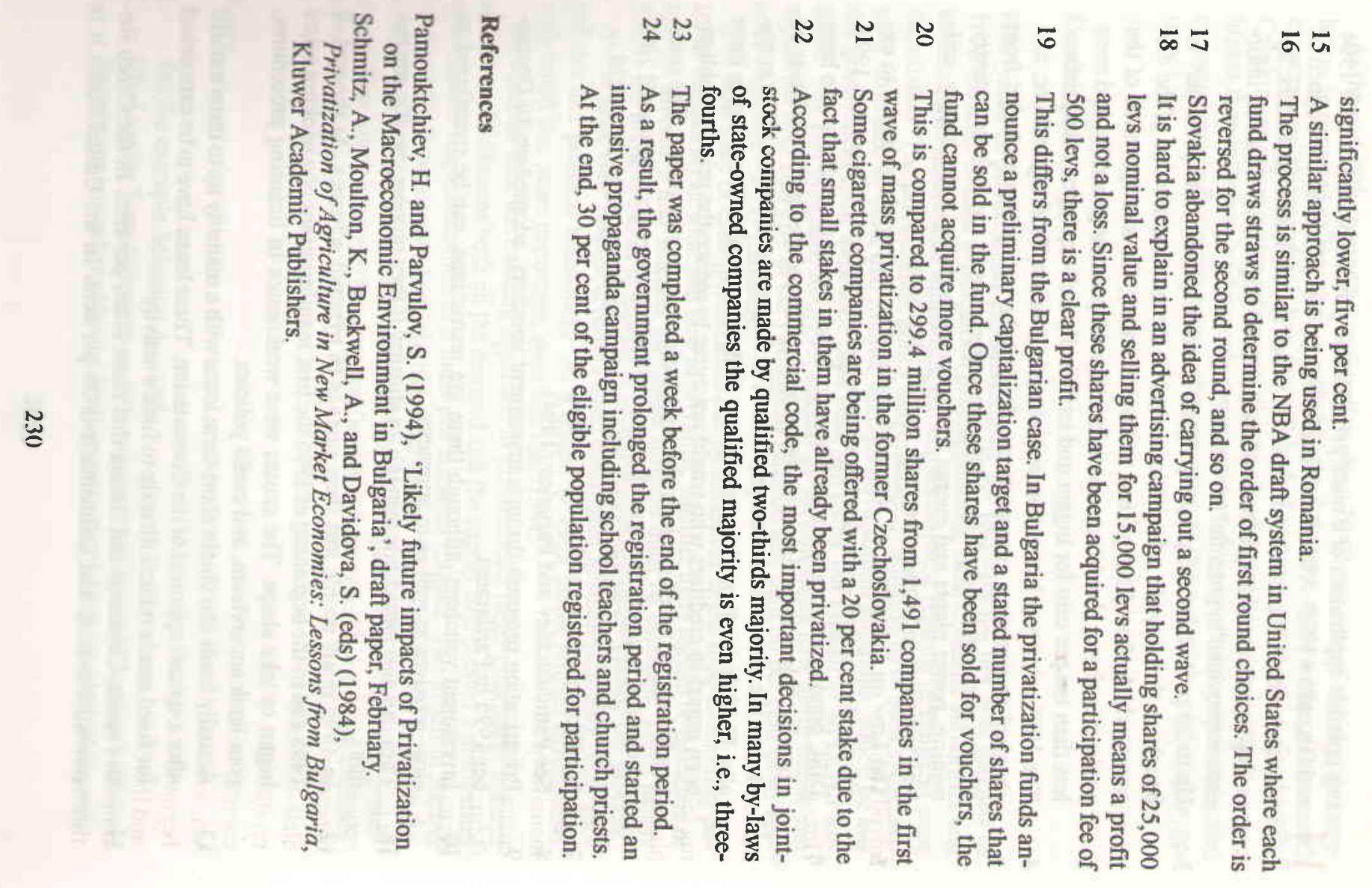

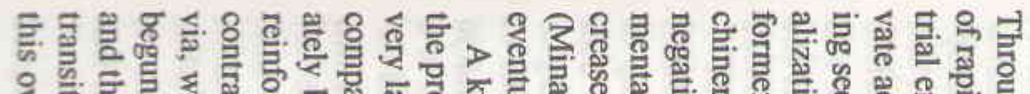

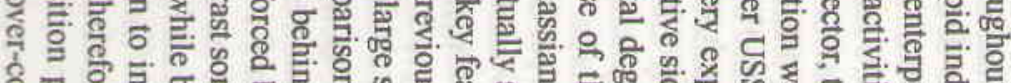

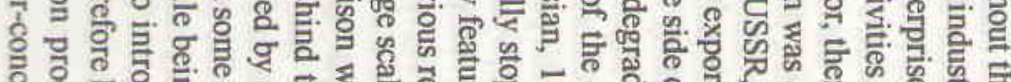

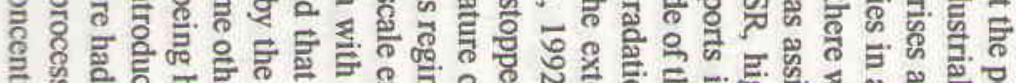

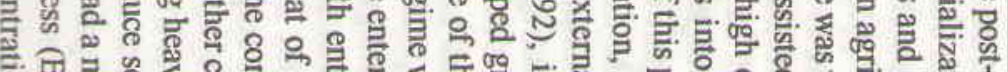

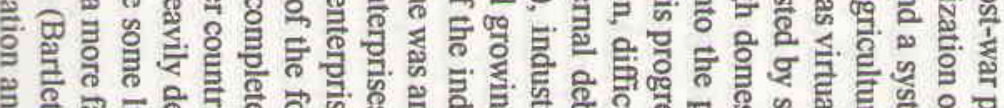

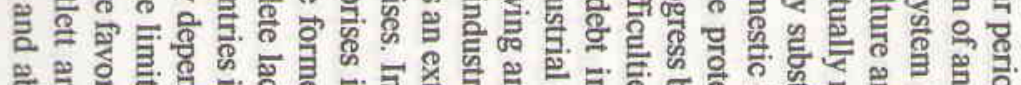

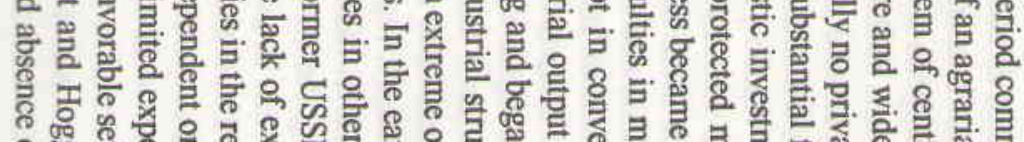

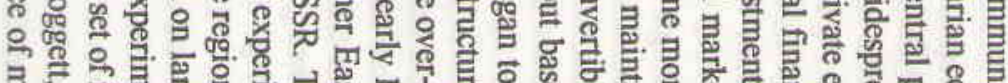

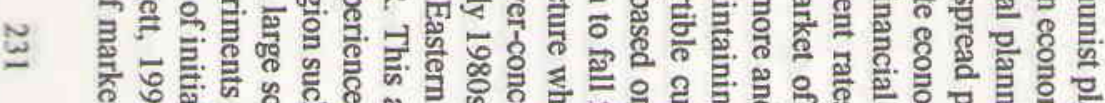

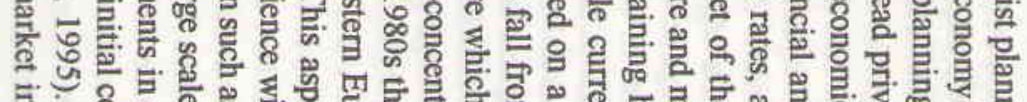

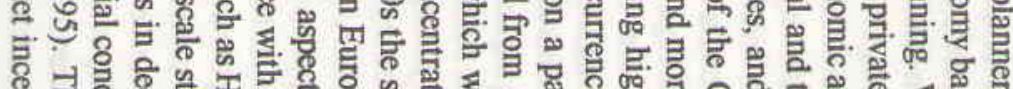
兽

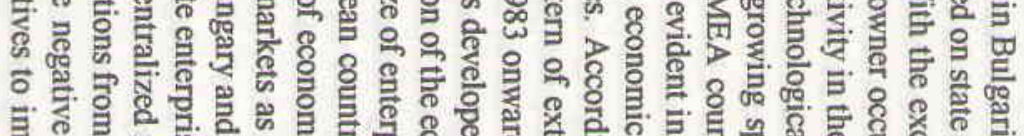

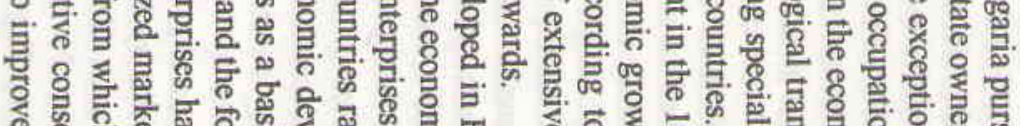
๒

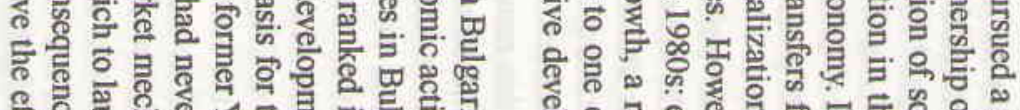

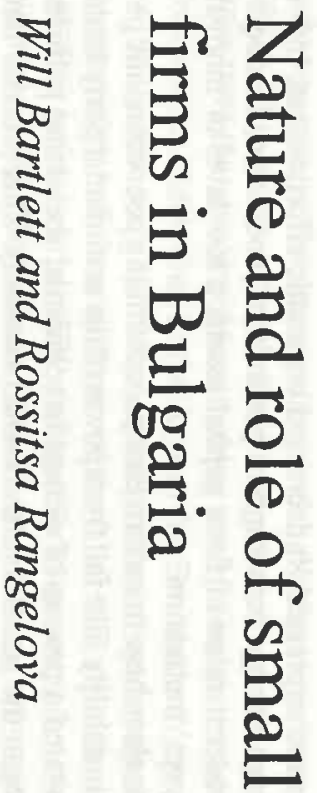

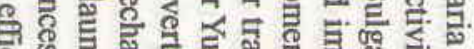

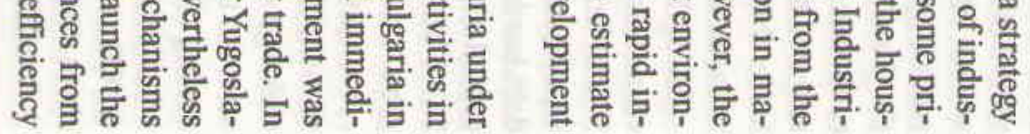

